Article

\title{
Seasonal Changes in Microbial Dissolved Organic Sulfur Transformations in Coastal Waters
}

\author{
Joanna L Dixon ${ }^{1, * \mathbb{D}}$, Frances E Hopkins ${ }^{1} \mathbb{D}$, John A Stephens ${ }^{1}$ and Hendrik Schäfer ${ }^{2}$ \\ 1 Plymouth Marine Laboratory, Prospect Place, West Hoe, Plymouth, Devon PL1 3DH, UK; \\ fhop@pml.ac.uk (F.E.H.); JAS@pml.ac.uk (J.A.S.) \\ 2 School of Life Sciences, University of Warwick, Gibbet Hill Road, Coventry CV4 7AL, UK; \\ H.Schaefer@warwick.ac.uk \\ * Correspondence: jod@pml.ac.uk; Tel.: +44-(0)1752-633100
}

Received: 13 December 2019; Accepted: 24 February 2020; Published: 27 February 2020

\begin{abstract}
The marine trace gas dimethylsulfide (DMS) is the single most important biogenic source of atmospheric sulfur, accounting for up to $80 \%$ of global biogenic sulfur emissions. Approximately 300 million tons of DMS are produced annually, but the majority is degraded by microbes in seawater. The DMS precursor dimethylsulfoniopropionate (DMSP) and oxidation product dimethylsulphoxide (DMSO) are also important organic sulfur reservoirs. However, the marine sinks of dissolved DMSO remain unknown. We used a novel combination of stable and radiotracers to determine seasonal changes in multiple dissolved organic sulfur transformation rates to ascertain whether microbial uptake of dissolved DMSO was a significant loss pathway. Surface concentrations of DMS ranged from 0.5 to $17.0 \mathrm{nM}$ with biological consumption rates between 2.4 and $40.8 \mathrm{nM} \cdot \mathrm{d}^{-1}$. DMS produced from the reduction of DMSO was not a significant process. Surface concentrations of total DMSO ranged from 2.3 to $102 \mathrm{nM}$ with biological consumption of dissolved DMSO between 2.9 and $111 \mathrm{nM} \cdot \mathrm{d}^{-1}$. Comparisons between ${ }^{14} \mathrm{C}_{2}$-DMSO assimilation and dissimilation rates suggest that the majority of dissolved DMSO was respired ( $>94 \%)$. Radiotracer microbial consumption rates suggest that dissimilation of dissolved DMSO to $\mathrm{CO}_{2}$ can be a significant loss pathway in coastal waters, illustrating the significance of bacteria in controlling organic sulfur seawater concentrations.
\end{abstract}

Keywords: dimethylsulfide; dimethylsulfoxide; bacteria; dissimilation to $\mathrm{CO}_{2}$; radiotracers; stable tracers; coastal variability

\section{Introduction}

The marine trace gas dimethylsulfide (DMS) is the single most important biogenic source of atmospheric sulfur [1]. It accounts for up to $80 \%$ of global biogenic sulfur emissions, and plays a key role in transporting sulfur to the terrestrial environment [2,3]. Approximately 300 million tons of DMS are produced annually in the marine environment [4]. However, only around $16 \%$ is transferred into the atmosphere [5], because the majority $(\sim 84 \%)$ is degraded by microbes in seawater [5-7]. The emission of DMS provides important precursors for the formation of secondary organic aerosols, and thus plays a vital role in atmospheric chemistry and climate processes [8,9]. In seawater, DMS along with its precursors (particulate and dissolved dimethylsulfoniopropionate; $\mathrm{DMSP}_{\mathrm{p}}$ and $\mathrm{DMSP}_{\mathrm{d}}$, respectively) provides important sources of carbon and sulfur for marine micro-organisms [10-13]. Microbial oxidation of DMS to dimethylsulfoxide (DMSO) in the mixed surface layer of the ocean is often the major sink for DMS $[13,14]$. However, the dominant processes affecting DMSO concentrations in marine waters remain largely unquantified, but microbes are likely to be key players determining not only marine DMS (and thus DMS flux to the atmosphere) and DMSP ${ }_{d}$, but also DMSO $\mathrm{d}_{\mathrm{d}}$ concentrations. 
The dominant source of DMS is thought to be via the microbial (bacteria and/or phytoplankton) enzymatic cleavage of algal-derived DMSP [15-17], although photochemically-derived production mechanisms [18] and DMSO reduction [15,19,20] could also contribute. The majority of DMSP in marine waters is particulate bound in intracellular pools ( $\mathrm{DMSP}_{\mathrm{p}}$ ), which gets released into the dissolved phase through algal cell lysis caused by grazing, viral attack or autolysis, or exudation [21,22]. Rapid utilization and turnover of $\mathrm{DMSP}_{\mathrm{d}}$ by bacteria, and some phytoplankton containing extracellular DMSP-lyases, typically maintains relatively low nano-molar concentrations [12].

Dimethylsulfoxide is also an important ubiquitous reservoir of organic sulfur in the ocean, where the total pool of DMSO is often greater than that of DMS [23], and equal to or greater than the total pool of DMSP $[20,24]$. Conventionally, the main sources of $\mathrm{DMSO}_{\mathrm{d}}$ are attributed to photochemical and microbial oxidation of DMS [14,25]. The microbial DMS oxidation process is thought to occur via a methylamine-dependent co-oxidation pathway, with bacteria like the marine Roseobacter clade using an enzyme called trimethylamine monooxygenase [26,27]. However, direct biosynthesis within cells $\left(\mathrm{DMSO}_{\mathrm{p}}\right)$ coupled with transformation to the dissolved phase via a number of pathways, including permeative diffusion, cell lysis, and as a byproduct of cell activity, have also been suggested $[25,28]$. The function of DMSO in cells is still under debate, but hypotheses revolve around cryoprotection, osmotic pressure regulation, modification of intracellular electrolytes, and oxidative stress defense $[25,29]$. The marine sinks of $\mathrm{DMSO}_{\mathrm{d}}$ remain essentially uncharacterised, although biological $\mathrm{DMSO}_{\mathrm{d}}$ consumption in seawater was previously observed [30,31]. Possible DMSO $\mathrm{DMss}_{\mathrm{d}}$ pathways include bacterial consumption, reduction to DMS, oxidation to dimethylsulphone, and export via sinking particles [32]. Several cultured phytoplankton species have been shown to reduce DMSO ${ }_{d}$ [33]. DMSO reductases are widespread in bacteria [34], and a variety of aerobic and anaerobic bacteria have been shown to reduce $\mathrm{DMSO}_{\mathrm{d}}$ to DMS during anaerobic respiration [19,35]. Growth on DMSO as a carbon source has also been reported for isolates of Hyphomicrobium [36], Arthrobacter [36,37], and Methylophaga [38]. However, our understanding of the production and consumption pathways of DMSO in the surface oceans and their controls are poorly understood [24].

Our objective was to employ a novel combination of stable and radiotracers in order to simultaneously determine seasonal changes in multiple dissolved organic matter sulfur transformation rates, and to ascertain whether microbial carbon $\mathrm{DMSO}_{\mathrm{d}}$ uptake and dissimilation to $\mathrm{CO}_{2}$ were significant $\mathrm{DMSO}_{\mathrm{d}}$ loss pathways. Our results suggest that dissimilation of dissolved $\mathrm{DMSO}$ to $\mathrm{CO}_{2}$ can be a significant loss pathway (for $\mathrm{DMSO}_{\mathrm{d}}$ ) in coastal waters.

\section{Materials and Methods}

Surface samples $(\leq 10 \mathrm{~m})$ were collected from the Western Channel Observatory long term monitoring station L4, situated $\sim 13 \mathrm{~km}$ south west of Plymouth (50.3 N, 04.22 W, water depth $55 \mathrm{~m}$ ). Water samples were collected by the RV Plymouth Quest using 10 L Niskin bottles mounted on a rosette sampler, which also housed a Seabird $19+$ CTD. Sub-samples were decanted into acid-washed brown glass bottles, sealed with ground glass stoppers with no headspace, and at in situ temperature for the $\sim 2 \mathrm{~h}$ transit back to the laboratory. Temperature variability during transit was $+1{ }^{\circ} \mathrm{C}$, which is within the in situ diurnal variability at station L4.

Seawater temperature was determined from the Seabird CTD, which has an accuracy of $\pm 0.001{ }^{\circ} \mathrm{C}$ [39]. The concentration of chlorophyll a, nutrients, bacteria, and phytoplankton community composition were determined weekly at station L4 as part of the western English Channel Observatory (https://www.westernchannelobservatory.org.uk/). Chlorophyll a concentrations were determined through fluorometric analysis of acetone extracted pigments [40]. Nutrient analysis was conducted using recognized analytical techniques for nitrate [41,42] and phosphate [43]. Numbers of bacterial cells were determined by flow cytometry (Accuri C6 instrument) using SYBR Green I DNA-stained cells to determine high nucleic acid (HNA) and low nucleic acid (LNA) containing cells from $1.8 \mathrm{~mL}$ seawater samples fixed in paraformaldehyde (5\% final concentration). Synechococcus sp. numbers were determined by flow cytometry (Accuri C6 instrument) on unstained samples based on their light 
scattering and autofluorescence properties [44]. Phytoplankton enumeration and composition were conducted using established microscopy [45].

\subsection{Organic Sulfur Concentrations}

Concentrations of DMS, DMSP, and DMSO in seawater were analysed sequentially using a purge and cryotrapping system coupled with sulfur specific gas chromatography using a Varian 3800 gas chromatograph with a pulsed flame photometric detector (GC-PFPD) using methodology described by Simó et al. [46], Simó and Vila-Costa [47], and Archer et al. [48], as modified by Vila-Costa et al. [12] for DMSO analysis. Briefly, for DMS, $5 \mathrm{~mL}$ samples were gently filtered through a $25 \mathrm{~mm} \mathrm{GF} / \mathrm{F}$ (glass fiber) filter directly into a purge tower, avoiding any contact with air, and immediately analysed via GC-PFPD (purged for $5 \mathrm{~min}$ at $60 \mathrm{~mL} \mathrm{~min}^{-1}$ and cryogenically trapped in a PTFE sample loop submerged in liquid nitrogen before desorption using boiling water to GC). For dissolved DMSP (DMSP $\mathrm{d}_{\mathrm{d}}$ ), the purged DMS sample was transferred to a glass vial with $10 \mathrm{M} \mathrm{NaOH}$ and hydrolysed for 6-24 h (to convert $\mathrm{DMSP}_{\mathrm{d}}$ to DMS). Following hydrolysis, samples were analysed as above. For dissolved DMSO $\left(\right.$ DMSO $_{\mathrm{d}}$ ), $\sim 10 \mathrm{mg}$ cobalt-doped $\mathrm{NaBH}_{4}$ was added to the purged DMSP $\mathrm{d}$ sample (which reduces $\mathrm{DMSO}_{\mathrm{d}}$ to DMS) and purged for a further $10 \mathrm{~min}$, with DMS analysis as previous.

For total DMSP $\left(\right.$ DMSP $\left._{\mathrm{t}}\right)$, which includes particulate DMSP (DMSP $\mathrm{p}$ ) and a minor fraction from dissolved DMSP $\left(\right.$ DMSP $\left._{\mathrm{d}}\right), 7 \mathrm{~mL}$ of whole seawater was pipetted into a glass vial with $1 \mathrm{~mL} 10 \mathrm{M}$ $\mathrm{NaOH}$, and left for 12-24 h for hydrolysis to convert DMSP to DMS. Then, $1 \mathrm{~mL}$ was carefully pipetted to a glass purge tower for extraction of DMS as above. For DMSP, $7 \mathrm{~mL}$ of whole seawater was gravity filtered through a $25 \mathrm{~mm} \mathrm{GF/F} \mathrm{filter.} \mathrm{The} \mathrm{filter} \mathrm{was} \mathrm{placed} \mathrm{in} \mathrm{a} \mathrm{glass} \mathrm{vial} \mathrm{with} 7 \mathrm{~mL} \mathrm{MQ}$ and $1 \mathrm{~mL} 10 \mathrm{M} \mathrm{NaOH}$, and left for 12-24 h for hydrolysis. Then, $1 \mathrm{~mL}$ was pipetted to the purge tower and analysed as previously. For particulate DMSO $\left(\mathrm{DMSO}_{\mathrm{p}}\right), \sim 10 \mathrm{mg}$ cobalt-doped $\mathrm{NaBH}_{4}$ was added to the purged $\mathrm{DMSP}_{\mathrm{p}}$ sample to reduce $\mathrm{DMSO}_{\mathrm{p}}$ to DMS, and subsequently analysed by GC as above. The detection limit of the system was approximately 2.9 pmol S. The standard deviation of at least duplicate experimental samples was on average $6 \%, 10 \%, 9 \%, 9 \%$, and $7 \%$ of the mean for DMS, DMSP $\mathrm{P}_{\mathrm{t}}$, $\mathrm{DMSP}_{\mathrm{p}}, \mathrm{DMSO}_{\mathrm{p}}$, and $\mathrm{DMSO}_{\mathrm{d}}$, respectively. DMS standards for calibration were prepared from DMSP (>98\% purity; Dr Sinan Battah, University of Essex, Colchester, UK) in a $10 \mathrm{M} \mathrm{NaOH}$ solution in Milli-Q water. Typically, 4-5-point calibration curves were carried out twice per month during the sampling period, with an $\mathrm{r}^{2}$ for the resulting linear regression of $\mathrm{ng}$ sulfur versus square root of the peak area of typically $\geq 0.996$.

We report DMS, DMSP $, \mathrm{DMSP}_{\mathrm{p}}, \mathrm{DMSO}_{\mathrm{p}}$, and $\mathrm{DMSO}_{\mathrm{d}}$ data. We additionally determined the change in concentration of DMS from Tedlar bag incubation experiments (see stable isotope tracer rate experiments below) by withdrawing $\sim 30 \mathrm{~mL}$ and immediately gently filtering through a Millipore filtration unit containing a $25 \mathrm{~mm}$ GF/F filter directly into a $20 \mathrm{~mL}$ glass receiving syringe (ensuring no headspace, bubbles, or exposure to the atmosphere). This was immediately injected into a purge tower, and purged with high purity nitrogen at a flow rate of $\sim 100 \mathrm{~mL} \mathrm{~min}^{-1}$ for 15 min directly into the proton transfer reaction mass spectrometer (m/z 66, PTR-MS, Ionicon, Innsbruck, Austria). This results in an exponentially decaying peak, allowing the total amount of DMS in a sample to be calculated by integration of the total peak area. Baseline levels were attained after 15 min of purging. Calibration curves were prepared using pure DMS (Merck, Gillingham, Dorset, UK). A primary DMS standard was prepared gravimetrically followed by dilution to produce a secondary standard, using gas tight vials. Five working (tertiary) standards were made up by dilution of the secondary standard in ultra-pure water in $100 \mathrm{~mL}$ glass syringes, to produce a 5-point calibration. For analysis, sub-samples of each standard were taken using $20 \mathrm{~mL}$ glass syringes without exposing the sample to the air, and purged and analyzed as above. Calibrations were performed on each sampling date. DMSP $\mathrm{D}_{\mathrm{d}}$ and $\mathrm{DMSO}_{d}$ were sequentially reduced to DMS after adding $\mathrm{NaOH}\left(\mathrm{DMSP}{ }_{\mathrm{d}}\right)$ and cobalt-doped $\mathrm{NaBH}_{4}$ $\left(\mathrm{DMSO}_{\mathrm{d}}\right)$ [12,47] into the purge tower and direct analysis by PTR-MS as above for the GC method. On 11 dates, DMS concentrations analysed via GC-PFPD and PTR-MS were compared and show good agreement: y (DMS PTR-MS) $=0.957$ x (DMS GC-PFPD), where $\mathrm{r}=0.962(n=11, p<0.001)$, suggesting 
that DMS concentrations derived from PTR-MS analysis were on average $4 \%$ lower than those from GC measurements.

\subsection{Stable Isotope Tracer Rate Experiments}

Isotope tracer incubation experiments were also conducted using surface waters collected from station L4 between May and October 2014. On each date, approximately $350 \mathrm{~mL}$ seawater was siphoned directly into four acid washed and rinsed Tedlar (1L, Supelco, from Merck, Gillingham, Dorset, UK)bags without exposure to ambient air. We simultaneously added DMS (d $\mathrm{d}_{3}$-DMS, 99 atom \% d, Merck, Gillingham, Dorset, UK), DMSP ${ }_{\mathrm{d}}$ (d6-DMSP 99 atom \% „, Australian Government, National Measurement Institute, Sydney, Australia) and $\mathrm{DMSO}_{\mathrm{d}}\left({ }^{13} \mathrm{C}_{2}\right.$-DMSO 99 atom $\%{ }^{13} \mathrm{C}$, Merck, Gillingham, Dorset, UK) at $\sim 10 \%$ of in situ concentrations into triplicate experimental bags. These and a control experimental bag (without any stable tracer additions) were incubated for 3-4 h in the dark at in situ temperature. During experiments, sub-samples were collected over 3-4 time points from each bag using a $50 \mathrm{~mL}$ glass syringe via the inlet on the Tedlar bag. Approximately $30 \mathrm{~mL}$ was withdrawn (ensuring no headspace or bubbles) at each time point and immediately gently filtered through a Millipore filtration unit containing a $25 \mathrm{~mm}$ GF/F filter directly into a $20 \mathrm{~mL}$ glass receiving syringe. This was immediately injected into a purge tower and analysed by PTR-MS as above. This technique allows the simultaneous quantification of DMS derived from DMSP cleavage and DMSO reduction, gross DMS loss (we assume this equates to biological consumption because photochemical reactions and sea to air flux were eliminated in our closed dark experimental bags), and net change in DMS concentrations (gross production-biological consumption). DMS production from DMS cleavage was determined as the rate of accumulation of $d_{6}$-DMS from $d_{6}$-DMSP, while DMS production from DMSO reduction was measured as the rate of accumulation of ${ }^{13} C_{2}$-DMS from ${ }^{13} C_{2}$-DMSO. Biological consumption of DMS was calculated from the rate of decrease in $\mathrm{d}_{3}$-DMS. Net change in DMS results from the rate of change of DMS, and thus gross DMS production, is calculated as net change in DMS plus biological consumption.

On two of the sampling dates (21 July and 26 August 2014), additional samples were also taken during the time course incubations for the determination of $\mathrm{DMSO}_{\mathrm{d}}$ derived from the microbial oxidation of DMS (rate of appearance of $\mathrm{d}_{3}$-DMSO from $\mathrm{d}_{3}$-DMS), the biological consumption of $\mathrm{DMSO}_{\mathrm{d}}$ (from loss of ${ }^{13} \mathrm{C}_{2}$-DMSO corrected for any conversion to ${ }^{13} \mathrm{C}_{2}$-DMS), and the biological consumption of DMSP ${ }_{d}$ (from loss of $d_{6}-$ DMSP $_{d}$ corrected for any conversion to $d_{6}$-DMS and $d_{6}-$ DMSP $_{d}$ ). For subsequent isotope $\mathrm{DMSP}_{\mathrm{d}}$ and $\mathrm{DMSO}_{\mathrm{d}}$ analysis at each time point, $20 \mathrm{~mL}$ was withdrawn from the Tedlar incubation bags using a glass syringe and placed immediately into a $20 \mathrm{~mL}$ serum vial containing two pellets of sodium hydroxide, which were immediately crimp sealed. These samples were stored in the dark at in situ temperature for between 4 and 8 weeks [49-51]. Before analysis by PTR-MS, $10 \mathrm{~mL}$ sub-samples were taken with a glass syringe and filtered as previously described. The filtered sub-sample was immediately injected in a purge tower. Stable isotopes of DMSP $\mathrm{D}_{\mathrm{d}}$ and $\mathrm{DMSO}_{\mathrm{d}}$ were sequentially reduced to DMS after adding $\mathrm{NaOH}\left(\mathrm{DMSP}_{\mathrm{d}}\right)$ and cobalt-doped $\mathrm{NaBH}_{4}$ $\left(\mathrm{DMSO}_{\mathrm{d}}\right)$ into the purge tower and direct analysis by PTR-MS as previously. Concentrations of stable isotopes were determined via PTR-MS at $\mathrm{m} / \mathrm{z}$ of $63,65,66$, and 69 for unlabeled DMS, ${ }^{13} \mathrm{C}_{2}$-DMS, $\mathrm{d}_{3}$-DMS, and $\mathrm{d}_{6}$-DMS, respectively (as this method of soft ionization within the PTR-MS adds a proton to each compound with no fragmentation of compounds). Final concentrations were calculated using standard curves. To scale the rate of tracer consumption or production to in situ values, the calculated rates were divided by the concentration of added tracer (yielding the apparent rate constant, $\mathrm{h}^{-1}$ ) and multiplied by the concentration of natural DMS, DMSP $\mathrm{d}_{\mathrm{d}}$, or $\mathrm{DMSO}_{\mathrm{d}}$ as appropriate [15]. Biological turnover times for DMS, DMSP $\mathrm{d}_{\mathrm{d}}$, and $\mathrm{DMSO}_{\mathrm{d}}$ were calculated from the inverse of the rate constants for the loss of $\mathrm{d}_{3}$-DMS, $\mathrm{d}_{6}-\mathrm{DMSP} \mathrm{d}_{\mathrm{d}}$, and ${ }^{13} \mathrm{C}_{2}-\mathrm{DMSO}_{\mathrm{d}}$, respectively. 


\subsection{Radiotracer Rate Experiments}

Seawater samples from the coastal station L4 were collected from Niskin bottles via acid washed Teflon tubing directly into the gas tight dark glass bottles $(305 \mathrm{~mL}$ volume, acid washed, and rinsed with hot water). Labelled ${ }^{14} \mathrm{C}_{2}$-DMSO was added to each bottle and incubated in the dark at in situ temperature (no headspace). Tracer nano-molar ( $\leq 1.6 \mathrm{nM}$, representing $\leq 4 \%$ in situ $\mathrm{DMSO}_{\mathrm{d}}$ concentrations) additions of ${ }^{14} \mathrm{C}_{2}-\mathrm{DMSO}_{\mathrm{d}}\left({ }^{14} \mathrm{CH}_{3} \mathrm{SO}^{14} \mathrm{CH}_{3}\right)$ were added to samples to determine microbial assimilation into biomass and dissimilation to ${ }^{14} \mathrm{CO}_{2}$. Labelled ${ }^{14} \mathrm{C}_{2}$-DMSO was purchased from American Radiolabeled Chemicals, Inc (St.Louis, Missouri, USA) with a specific activity of $30 \mathrm{mCi}$ $\mathrm{mmol}^{-1}$ and a radiochemical purity of $>99 \%$ (based on high performance liquid chromatography). A primary stock was made by diluting $52 \mu \mathrm{Ci}$ into $25 \mathrm{~mL}$ of $18 \mathrm{M} \Omega$ milli-Q water $\left(2.1 \mu \mathrm{Ci} \mathrm{mL} \mathrm{m}^{-1}\right)$, and was stored in gas tight amber vials in the dark at $4{ }^{\circ} \mathrm{C}$. Storage trials suggest $<6 \%$ loss in activity over 12 months. Addition volumes of ${ }^{14} \mathrm{C}_{2}$-DMSO to seawater samples were $<1 \%$ of the sample volume incubation experiments.

\subsubsection{Carbon Assimilation from $\mathrm{DMSO}_{\mathrm{d}}$}

For $\mathrm{DMSO}_{\mathrm{d}}$ carbon assimilation, a volume of $100 \mathrm{~mL}$ of the seawater sample was withdrawn from the bottom of the gas tight sampling bottles with a Teflon tube attached to a gas tight glass syringe. The tube was detached and the glass syringe attached to a Swinnex filter holder containing a $47 \mathrm{~mm}$ Supor $0.2 \mu \mathrm{m}$ filter [47]. Supor filters $(0.2 \mu \mathrm{m})$ were used because of their superior retention of particulate material [52]. Procedural blanks were routinely assessed by incubating $0.2 \mu \mathrm{m}$ filtered seawater (with added Mercuric Chloride, $0.01 \%$ final concentration) and filtration, resulting in average counts of $<60 \pm 3$ DPM per filter ( $n=10$, for $\sim 34,000$ DPM added per incubation). Samples and procedural blanks were filtered in a downward position with application of a very gentle pressure (as in Simó \& Vila-Costa [47]). It took about 6-8 min to filter each sample. Filters were rinsed (using a three-way luer lock and pre-loaded $2 \mathrm{~mL}$ syringe) with approximately $2 \mathrm{~mL}$ of $0.2 \mu \mathrm{m}$ filtered seawater (but were not allowed to dry out). Filters were placed into scintillation vials, covered with $4 \mathrm{~mL}$ liquid scintillation fluid (Optiphase HiSafe 3; Perkin-Elmer, High Wycombe, UK), and counted on a Tri-carb 3100 (Perkin Elmer, High Wycombe, UK) liquid scintillation counter. Typically, for seawater samples, the coefficient of variation based on 3-6 replicates is $<3 \%$. It is possible that filtration artefacts caused release of $\mathrm{DMSO}_{\mathrm{d}}$ from particulate material ( $c f$. DMSP, Kiene \& Slezak [53]), so DMSO assimilation rates should be considered as minimal estimates. Exposure of filters to air at the end of filtration was avoided in our approach, which has previously been reported to cause severe DMSP ${ }_{d}$ release [53].

\subsubsection{Carbon Dissimilation to $\mathrm{CO}_{2}$ from $\mathrm{DMSO}_{\mathrm{d}}$}

$\mathrm{DMSO}_{\mathrm{d}}$ carbon microbial oxidation to ${ }^{14} \mathrm{CO}_{2}$ (dissimilation) was determined in triplicate by pipetting $1 \mathrm{~mL}$ samples (each from replicate $305 \mathrm{~mL}$ gas tight incubation bottles) into $2 \mathrm{~mL}$ micro centrifuge tubes (o ring sealed), and adding $0.5 \mathrm{~mL}$ of $\mathrm{SrCl}_{2} \cdot 6 \mathrm{H}_{2} \mathrm{O}\left(1 \mathrm{M}\right.$ to precipitate the ${ }^{14} \mathrm{CO}_{2}$ as $\left.\mathrm{Sr}^{14} \mathrm{CO}_{3}\right), 20 \mu \mathrm{L}$ of $\mathrm{NaOH}\left(1 \mathrm{M}\right.$, to neutralise the $\mathrm{HCl}$ produced), and $100 \mu \mathrm{L}$ of $\mathrm{Na}_{2} \mathrm{CO}_{3}$ (1 M, to ensure adequate pellet formation) (as in Goodwin et al. [54] for ${ }^{14} \mathrm{C}$ labelled methyl halides). The efficiency of the process assessed by mass balance of added ${ }^{14} \mathrm{C}$ label was $96 \% \pm 3 \%(n=6)$. After centrifugation, the supernatant was aspirated and the pellet washed twice with ethanol (80\%), resuspended in $1 \mathrm{~mL}$ of $\mathrm{NaOH}$ solution $(\sim 10 \mathrm{nM})$ that had been adjusted to a $\mathrm{pH}$ of 11.7 , before addition of Optiphase HiSafe III scintillant to create a slurry. The samples were vortex mixed and stored in the dark for $>24 \mathrm{~h}$ before being analysed on the scintillation counter. This period ensures that any chemiluminescence arising from interactions between the added $\mathrm{NaOH}$ and the Optiphase scintillant subsides [52]. Procedural blanks were routinely assessed as previously described, and resulted in average counts of $<22 \pm 7 \mathrm{DPM} \mathrm{mL}^{-1}$ ( $n=10$, for $\sim 34000$ DPM added per incubation).

Microbial assimilation and dissimilation rates of $\mathrm{DMSO}_{\mathrm{d}}$ were determined from linear time course experiments (refer to Figure S1), where the apparent rate constants $\mathrm{k}\left(\mathrm{h}^{-1}\right)$ was initially calculated 
from a ratio of the ${ }^{14} \mathrm{C}$ counts collected on either the filter (assimilation) or as precipitated ${ }^{14} \mathrm{CO}_{2}$ (dissimilation, DPM mL ${ }^{-1} \cdot \mathrm{h}^{-1}$ ) divided by the ${ }^{14} \mathrm{C}_{2}$-DMSO spike (DPM mL ${ }^{-1}$ ). The apparent rate constant was multiplied by the in situ concentration of $\mathrm{DMSO}_{\mathrm{d}}$ to calculate $\mathrm{DMSO}_{\mathrm{d}}$ assimilation or dissimilation rates $\left(\mathrm{nM} \mathrm{d}^{-1}\right)$. All rate constants were corrected by subtracting killed sample counts. In addition, dissimilation rates were corrected to account for a minor (typically $<1 \%$ ) contribution from assimilation into particles entrained within the $\mathrm{Sr}^{14} \mathrm{CO}_{3}$ precipitate.

\section{Results}

\subsection{Environmental and Biological Variables at Station L4}

Station L4 is situated in northern temperate waters (salinity 35.0 PSU [39]) and, typically, surface water temperature does not increase above $10^{\circ} \mathrm{C}$ until mid-April (Figure 1a). This is coincident with decreasing nutrient concentrations (Figure 1b), increasing concentrations of chlorophyll a (Figure 1c), and the start of water column stratification [39]. Average winter (Jan-Mar) nitrate and phosphate concentrations were $8.6 \pm 0.6$ and $0.6 \pm 0.1 \mu \mathrm{M}$, respectively. Concentrations of nitrate and phosphate rapidly declined to $<0.1 \mu \mathrm{M}$ by the beginning of June and generally remain limited until early October, when the water column becomes fully mixed and nutrients begin to increase to typical winter values coincident with the decreasing sea surface temperature (Figure 1). The concentration of chlorophyll a showed a maxima mid-April of $2.4 \mu \mathrm{g} \mathrm{L}^{-1}$ (Figure 1c), which is average compared with the long term trends (1992-2008 Smyth et al. [39]). This peak was associated with a typical spring diatom bloom

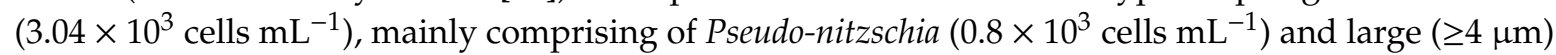
Thalassiosira phytoplankton cells $\left(2.2 \times 10^{3}\right.$ cells $\mathrm{mL}^{-1}$ Figure $\left.2 \mathrm{a}\right)$. This was followed in May by a slightly smaller chlorophyll a peak $\left(1.8-2.0 \mu \mathrm{g} \mathrm{L}^{-1}\right.$, Figure 1c), but longer lasting phytoplankton bloom consisting mainly (23-55\% of total phytoplankton) of Phaeocystis $\left(1.5-4.4 \times 10^{3}\right.$ cells $\mathrm{mL}^{-1}$ Figure 2a). Thereafter, chlorophyll a concentrations generally showed a decreasing pattern for the rest of 2014 (Figure 1c). From mid-July to mid-September, the phytoplankton was dominated by phytoflagellates $(\sim 2-5 \mu \mathrm{m})$ and did not show the more typical late August/September dinoflagellate bloom [39]. There was a relatively small bloom of Emiliania huxleyi during late August (up to $1.1 \times 10^{3} \mathrm{cells} \mathrm{mL}^{-1}$ Figure 2a). The two relatively small peaks in dinoflagellate abundance that occurred during June and July (Figure $2 b$ ) were dominated by Heterocapsa sp. (118 cells $\mathrm{mL}^{-1}, 90 \%$ of total Dinoflagellate species) and Neoceratium lineatum (118 cells $\mathrm{mL}^{-1}, 97 \%$ of total dinoflagellate species), respectively. From flow cytometry analysis, the numbers of nanophytoplankton $(2-20 \mu \mathrm{m})$, picophytoplankton $(<2.0 \mu \mathrm{m})$, and Synechococcus ranged between 0.12 and 15.9, 1.46 and 41.5, and 0.15 and $62.0 \times 10^{3}$ cells $\mathrm{mL}^{-1}$, respectively, and showed peaks in abundance during September (Figure 2c). Total bacteria ranged between 2.87 and $22.3 \times 10^{5}$ cells $\mathrm{mL}^{-1}$ and were generally dominated by the high nucleic acid fraction. Bacterial numbers were generally highest during June-September months (Figure 2d).

\subsection{DMS, DMSP, and DMSO Concentrations}

Near surface concentrations of DMS ranged from $0.5 \mathrm{nM}$ during October to a maximum of $17.0 \mathrm{nM}$ in mid-June (Figure 3a). While DMS concentrations close to the bottom at $50 \mathrm{~m}$ showed less pronounced variability, ranging between 0.4 and $5.0 \mathrm{nM}$. Total DMSP near surface concentrations did not show any distinct maxima like DMS, but were on average $68.1 \pm 18.5 \mathrm{nM}$ during spring and summer months before generally decreasing to $10.6 \pm 0.4 \mathrm{nM}$ in October (Figure 3b). In close to bottom waters, $\mathrm{DMSP}_{\mathrm{t}}$ concentrations averaged $13.5 \pm 8.9 \mathrm{nM}$ (June-October). However, there were noticeably higher concentrations during May (average $108.0 \pm 36.0 \mathrm{nM}$, Figure $3 \mathrm{~b}$ ), which could have been because of decaying and/or settling Phaeocystis cells, which were relatively abundant during this month (Figure 2a). The DMS/DMSP $P_{t}$ ratio (Figure 3a) clearly followed the same pattern as the DMS, suggesting that elevated DMS concentrations were not just a product of higher concentrations of DMSP $_{t}$. For near surface waters, $66-100 \%$ of the DMSP $_{t}$ was particulate $(57-100 \%$ for near bottom samples). The total DMSO concentration in surface waters ranged between 2.3 and $102 \mathrm{nM}$, with on 
average $\sim 56 \%$ in the dissolved phase (Figure 3c). The maxima in $\mathrm{DMSO}_{\mathrm{t}}$ occurred during June, coincident with a relatively high concentration of DMS at $11.4 \mathrm{nM}$. Minima in $\mathrm{DMSO}_{\mathrm{t}}$ concentrations were observed during autumn months, and were on average $7.0 \pm 1.0 \mathrm{nM}$.
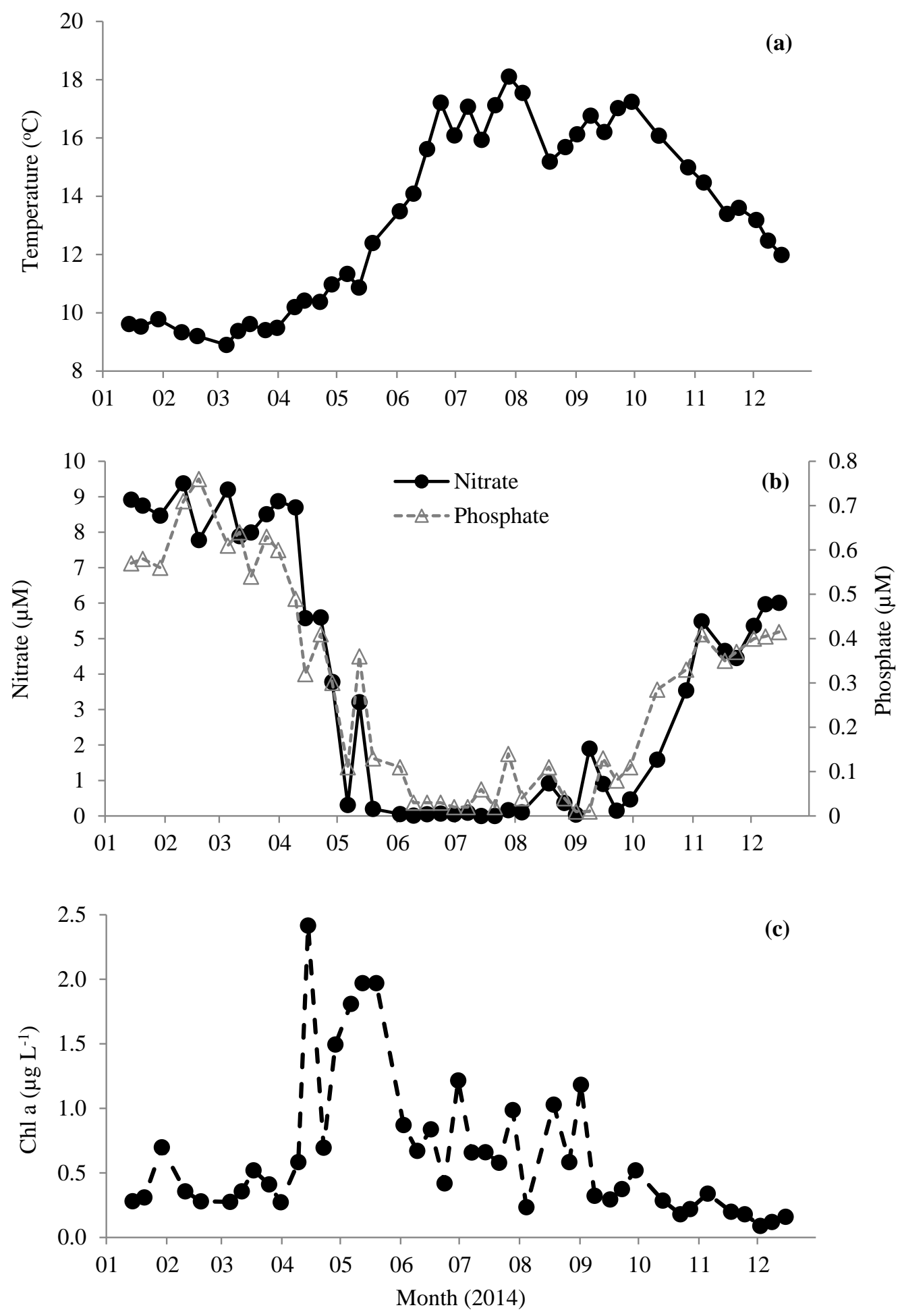

Figure 1. Change in (a) sea surface temperature, (b) inorganic nutrient concentrations of nitrate and phosphate, and (c) chlorophyll a in surface waters of station L4 in the western English Channel during 2014. 

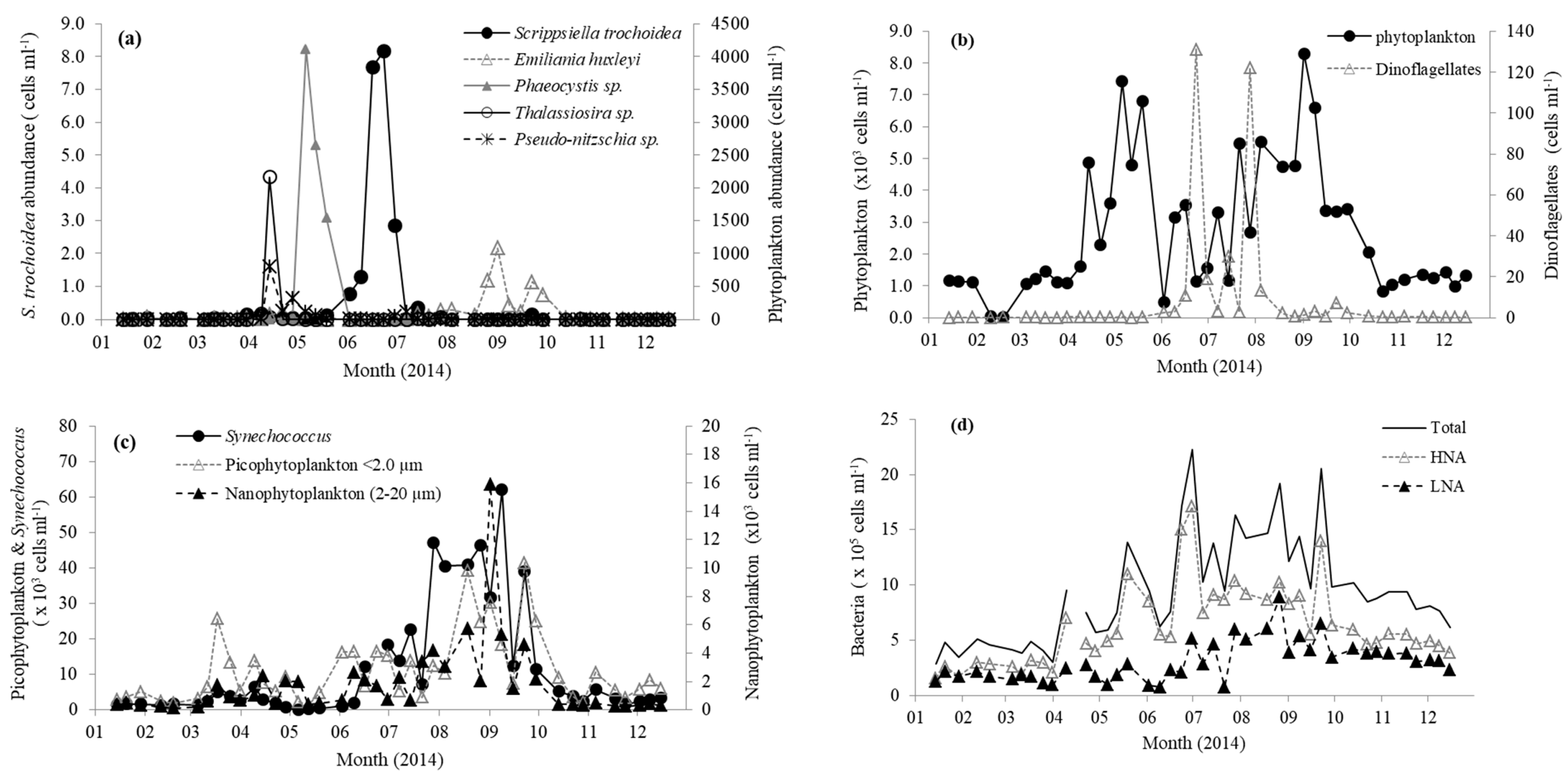

Figure 2. Abundance of (a) individual phytoplankton species; (b) total phytoplankton and dinoflagellate cells; (c) Synechococcus, pico, and nanophytoplankton; and (d) total bacterioplankton in surface waters of station L4 in the western English Channel during 2014. HNA, high nucleic acid; LNA, low nucleic acid. 

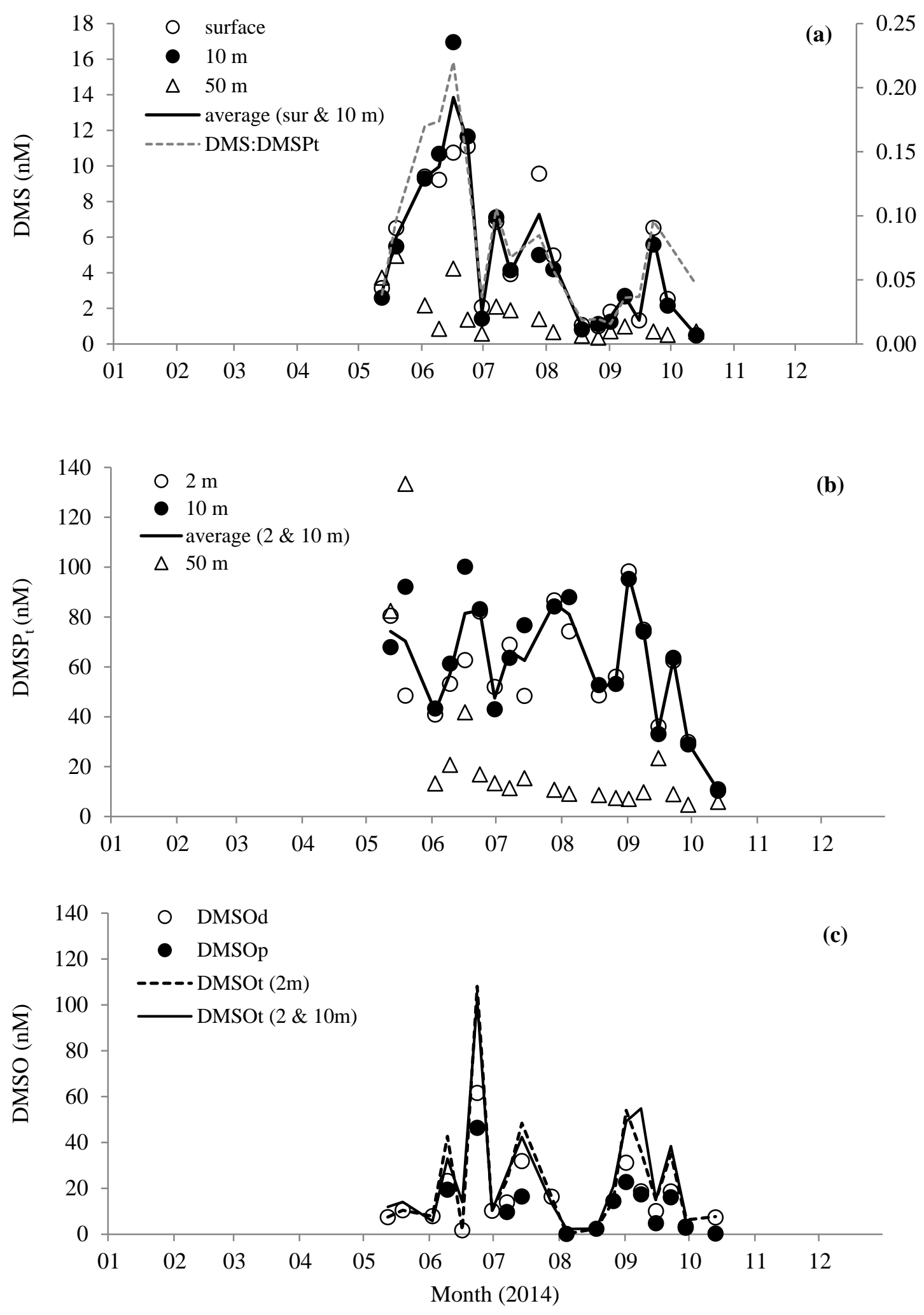

Figure 3. Changes in concentrations of (a) dimethylsulfide (DMS) and average molar ratio of DMS/total dimethylsulfoniopropionate $\left(\mathrm{DMSP}_{\mathrm{t}}\right),(\mathbf{b}) \mathrm{DMSP}_{\mathrm{t}}$, and (c) dimethylsulphoxide (DMSO) measured in the water column at station L4. 


\subsection{Stable-Isotope Tracer Experiments}

Biological consumption of DMS (DMS BC) ranged between 2.4 and $40.8 \mathrm{nM} \mathrm{d}^{-1}$ (Figure 4a). The average DMS BC was $5.5 \pm 2.3 \mathrm{nM} \mathrm{d}^{-1}(n=8)$, excluding the three maxima that occurred during June and September. Net DMS production (change in ${ }^{12} \mathrm{C}$-DMS with time) ranged between 0.0 and $10.5 \mathrm{nM} \mathrm{d}^{-1}$ (average $3.7 \pm 3.4 \mathrm{nM} \mathrm{d}^{-1} n=12$ ). Summing net DMS production and DMS BC yields gross DMS production rates of $2.7-42.9 \mathrm{nM} \mathrm{d}^{-1}$ (average $14.4 \pm 11.2 \mathrm{nM} \mathrm{d}^{-1}, n=11$ Figure $4 \mathrm{a}$ ). We only detected DMS production from DMSP cleavage on half of the sampling dates ranging between 0.2 and $21.5 \mathrm{nM} \mathrm{d}^{-1}$ (Figure 4b). DMS produced from the reduction of DMSO was only detected at the beginning of September $\left(1.2 \pm 0.0 \mathrm{nM} \mathrm{d}^{-1}\right.$, Figure $\left.4 \mathrm{~b}\right)$, and was thus not a significant process during May-September 2014.

We determined changes in concentrations of $\mathrm{d}_{6}-\mathrm{DMSP}_{\mathrm{d}}$ and ${ }^{13} \mathrm{C}_{2}-\mathrm{DMSO}_{\mathrm{d}}$ on two dates in July and August (organic $S$ transformations are summarized in Figure 5). There was a net loss of DMSP (loss of ${ }^{12} \mathrm{C}_{-} \mathrm{DMSP}_{\mathrm{d}}$ ) of $20.7 \pm 8.8$ and $29.2 \pm 13.5 \mathrm{nM} \mathrm{d}^{-1}$ on $21 \mathrm{July}$ and 26 August, respectively. We calculated biological consumption of DMSP as $75.7 \pm 14.3$ and $48.4 \pm 15.6 \mathrm{nM} \mathrm{d}^{-1}$ for July and August, respectively (Figure 5). During these two experiments, we did not detect any DMSP ${ }_{d}$ cleavage or any direct oxidation of $\mathrm{DMSP}_{\mathrm{d}}$ to $\mathrm{DMSO}_{\mathrm{d}}$, and thus we calculated gross DMSP $\mathrm{d}$ production (biological DMSP $_{d}$ consumption - net loss of $\mathrm{DMSP}_{\mathrm{d}}$ ) of at least 55.0 and $19.2 \mathrm{nM} \mathrm{d}^{-1}$ for July and August, respectively (Figure 5). Biological consumption of $\mathrm{DMSO}_{\mathrm{d}}$ was $23.2 \pm 5.9$ and $25.6 \pm 11.6 \mathrm{nM} \mathrm{d}^{-1}$ for July and August, respectively (Figure 5). We observed a net loss of $\mathrm{DMSO}_{\mathrm{d}}\left(\right.$ loss of ${ }^{12} \mathrm{C}-\mathrm{DMSO}_{\mathrm{d}}$ ) of $8.1 \pm 3.3$ and $18.9 \pm 11.3 \mathrm{nM} \mathrm{d}^{-1}$, and thus calculated that gross $\mathrm{DMSO}_{\mathrm{d}}$ production must be at least $15.1 \pm 6.4$ and $6.7 \pm 16.2 \mathrm{nM} \mathrm{d}^{-1}$ for July and August, respectively (Figure 5).

\subsection{Radiotracer Experiments}

When nano-molar concentrations of ${ }^{14} \mathrm{C}_{2}-\mathrm{DMSO}_{\mathrm{d}}$ were added to seawater samples, ${ }^{14} \mathrm{C}$-carbon was incorporated into cellular biomass and respired to ${ }^{14} \mathrm{CO}_{2}$ linearly for $\sim 3.5 \mathrm{~h}$ (for examples, see Figure S1). Thus, marine microbes assimilated and dissimilated $\mathrm{DMSO}_{\mathrm{d}}$ carbon, using it for growth and energy. Microbial uptake of $\mathrm{DMSO}_{\mathrm{d}}$ into biomass (assimilation) ranged between $<0.01$ and $0.49 \mathrm{nM} \mathrm{d}^{-1}$ during June-December July 2014, and was at a maximum during summer months (Figure 4c). Microbial conversion of carbon from $\mathrm{DMSO}_{\mathrm{d}}$ to $\mathrm{CO}_{2}$ (dissimilation) was significantly higher and ranged between 2.7 and $111.0 \mathrm{nM} \mathrm{d}^{-1}$, with maximum rates during June (Figure 3c). The combination of DMSO assimilation and dissimilation thus ranged between 2.9 and $111.0 \mathrm{nM} \mathrm{d}^{-1}$, with between $<0.1 \%$ and $5.3 \%$ of $\mathrm{DMSO}_{\mathrm{d}}$ being used for microbial growth, although this may represent a lower limit if filtration artefacts led to significant cell lysis and subsequent loss of assimilated DMSO. 

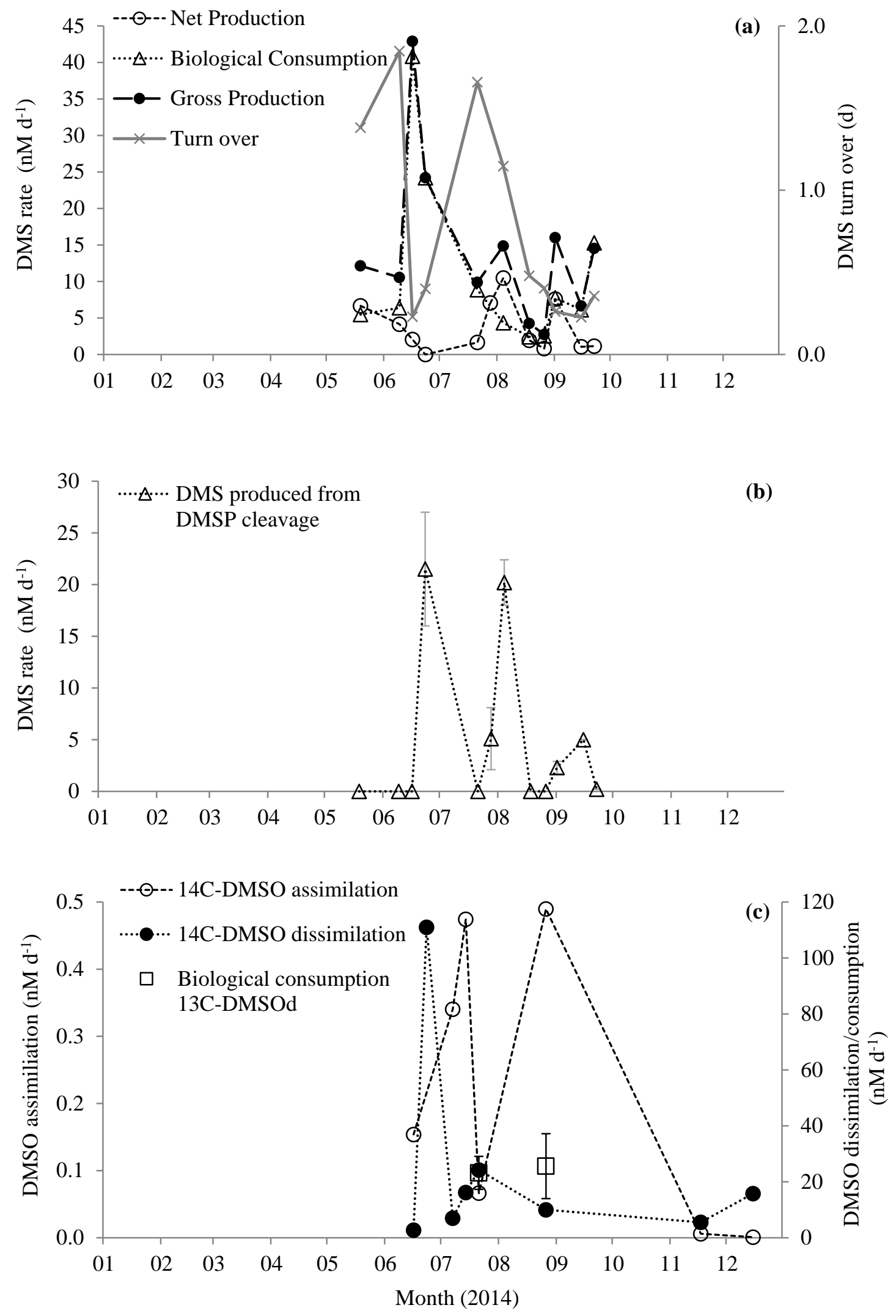

Figure 4. Changes in rates of (a) production and consumption of DMS and turn over time, (b) DMS produced from the cleavage of DMSP, and (c) microbial utilization of DMSO in surface waters at station L4. Error bars represent \pm 1 standard deviation based on three replicates. 
(a) Mid-high DMS (14.0 nM, 21" July 2014)

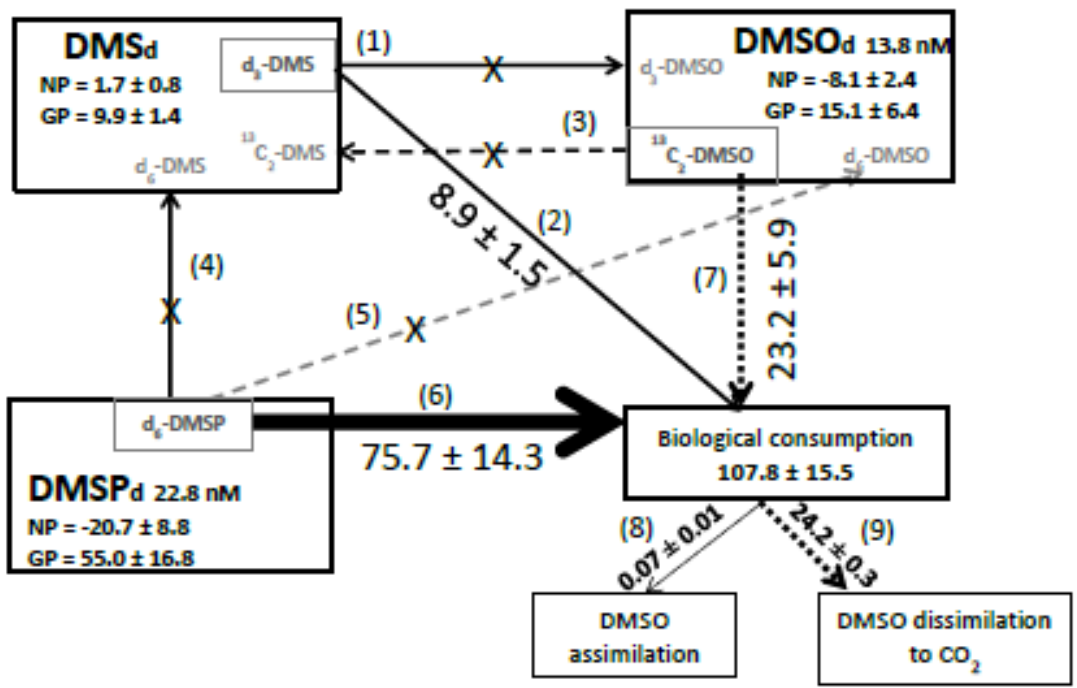

(b) Low DMS (1.0 nM, 26 ${ }^{\mathrm{A}}$ August 2014)

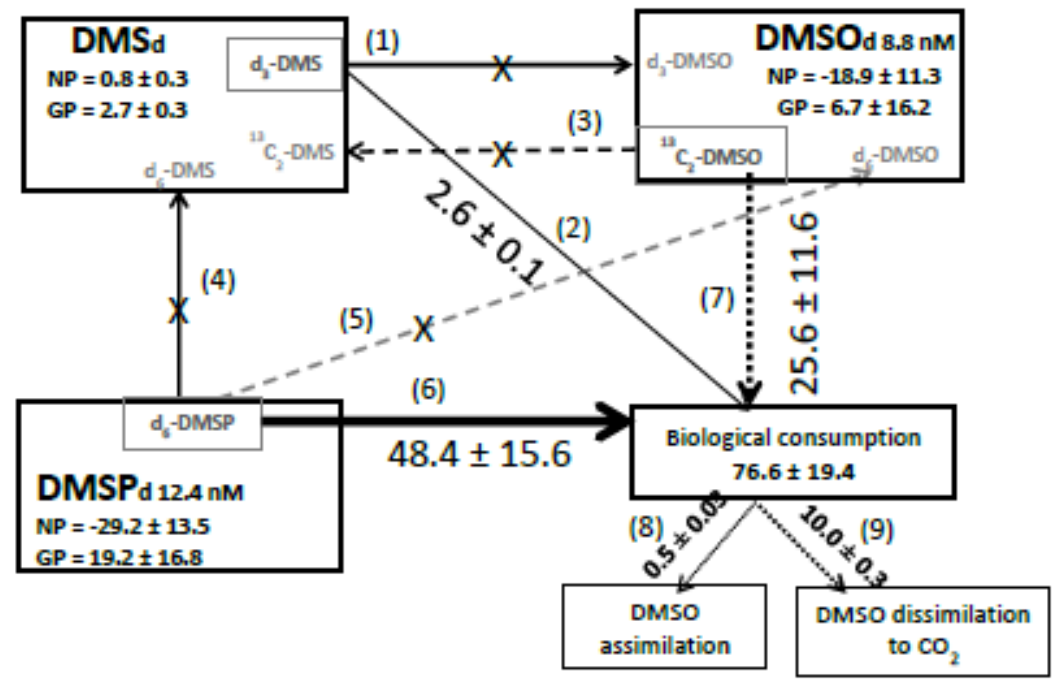

Figure 5. Box model summarising organic sulfur transformation rates $\left(\mathrm{nM} \mathrm{d}^{-1}\right)$ under $(\mathbf{a})$ mid-high concentrations of DMS (14.0 nM, sampled on 21 July 2014) and (b) low concentrations of DMS (1.0 nM sampled on 26 August 2014). These were the only two dates when all organic sulfur transformation rates were simultaneously determined. NP refers to net production and GP to gross production. Added stable tracers (in grey boxes) and their transformation products are indicated in grey text. Transformations labelled 1-9 are all microbial processes: (1) oxidation of DMS to $\mathrm{DMSO}_{\mathrm{d}}$ (appearance of $\mathrm{d}_{3}$-DMSO), (2) consumption of DMS (corrected loss of $\mathrm{d}_{3}$-DMS), (3) reduction of DMSO $\mathrm{d}_{\mathrm{d}}$ to DMS (appearance of ${ }^{13} C_{2}$ DMS), (4) enzymatic cleavage of DMSP $P_{d}$ to DMS (appearance of $d_{6}$-DMS), (5) conversion of $\mathrm{DMSP}_{\mathrm{d}}$ to $\mathrm{DMSO}_{\mathrm{d}}$ (appearance of $\mathrm{d}_{6}$-DMSO), (6) consumption of $\mathrm{DMSP}_{\mathrm{d}}$ (corrected loss of $\mathrm{d}_{6}$-DMSP), (7) consumption of $\mathrm{DMSO}_{\mathrm{d}}$ (corrected loss of ${ }^{13} \mathrm{C}_{2}-\mathrm{DMSO}_{\mathrm{d}}$ ), (8) $\mathrm{DMSO}_{\mathrm{d}}$ assimilation for growth (incorporation of ${ }^{14} \mathrm{C}-\mathrm{DMSO}_{\mathrm{d}}$ into the particulate phase), and (9) $\mathrm{DMSO}_{\mathrm{d}}$ dissimilation to $\mathrm{CO}_{2}\left({ }^{14} \mathrm{CO}_{2}\right.$ precipitated as $\left.{ }^{14} \mathrm{CO}_{3}\right)$. An " $\mathrm{X}$ " denotes no detectable rate was determined during the incubation experiment. Rates are shown as \pm 1 standard deviation based on three replicates.

\section{Discussion}

The average surface DMS concentration found at L4 between May and October 2014 was $5.1 \pm 4.0 \mathrm{nM}$, which compares well with the average found in U.K. shelf waters over the same 
monthly span of $5.4 \pm 8.6 \mathrm{nM}$ (data retrieved from the Global Surface Seawater DMS database: http://saga.pmel.noaa.gov/dms, number of records 2637). The ranges of DMS, DMSP $t_{t}$, and DMS/DMSP presented here also agree with those found in a previously published seasonal cycle at L4 [55]. Variations in DMS and DMSP are partly a consequence of taxonomic succession, particularly of dinoflagellate species $[55,56]$. Our maximum DMS was $\sim 6 \mathrm{nM}$ lower than Archer et al. [55], possibly reflecting the absence of Karenia mikimotoi (cf. $\sim 100$ cells $\mathrm{mL}^{-1}$ in Archer et al. [55]) and lower numbers of Scrippsiella trochoidea (8.2 compared with 25 cells $\mathrm{mL}^{-1}$ in Archer et al. [55]). Surface DMS concentrations showed a statistically significant positive correlation with the total abundance of dinoflagellate cells $(r=0.529$, $n=19 p=0.02$ ), perhaps reflecting the ability of several species, for example, Scrippsiella trochoidea and Heterocapsa triquetra, to directly produce DMS by cleaving dissolved DMSP [57-60]. Interestingly, there was a bloom of Heterocapsa sp. on 23 June 2014 (118 cells $\left.\mathrm{mL}^{-1}\right)$, which may have also contributed to the DMS maxima observed at this time. The range in $\mathrm{DMSP}_{\mathrm{t}}$ concentrations found at the coastal L4 station is within the range often reported for a variety of other marine environments, including the North Sea, North Atlantic, Mediterranean, and subarctic Pacific [20,30], but did not reach the elevated concentrations associated with intense dinoflagellate or Phaeocystis sp. blooms $(>200 \mathrm{nM})[30,61,62]$. The majority of the DMSP was in the particulate phase, as usually reported $[24,30,56,62]$. The average $\mathrm{DMSP}_{\mathrm{p}} / \mathrm{DMSO}_{\mathrm{p}}$ for our study was $5.4 \pm 4.8$, in agreement with the average reported in Simó \& Vila-Costa [47]. In comparison with DMS and DMSP, concentrations of DMSO are relatively less well documented [32]. During the majority of our sampling dates, surface $\mathrm{DMSO}_{t}$ concentrations remained lower than $\mathrm{DMSP}_{t}$ concentrations, with maximum values not exceeding $\sim 50 \mathrm{nM}$, as was similarly reported for coastal Antarctic waters [20]. Our $\mathrm{DMSO}_{t}$ values are within ranges reported globally $[24,30,32,47]$. One notable exception was a large peak of $\mathrm{DMSO}_{t}\left(\mathrm{DMSO}_{\mathrm{d}} 62 \mathrm{nM}, \mathrm{DMSO}_{\mathrm{p}}\right.$ $46 \mathrm{nM}$ ), which corresponded to an over 140-fold increase in the number of dinoflagellate cells from a pre-bloom average of 0.91 to 131 cell $\mathrm{mL}^{-1}$. During this time, the dinoflagellate abundance was dominated $(90 \%)$ by Heterocapsa cells, which were previously absent. We thus hypothesise that either there is direct production of $\mathrm{DMSO}_{\mathrm{d}}$ from the high-DMSP producing Heterocapsa [58], or the bacterial

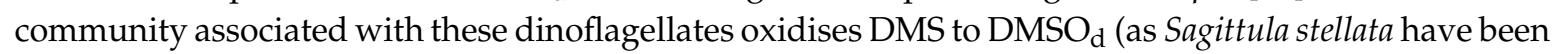
shown to do using DMS as an energy source [63]) or metabolises DMSP straight to DMSO. Dominant pelagic bacteria such as the marine Roseobacter clade are thought to use methylamine-dependent monoxygenases to oxidise DMS to DMSO [27]. This trimethylamine monoxygenase is also present in the SAR11 clade, which, together with the Roseobacter group, could account for $20 \%$ of bacterial cells in surface seawater [27]. The SAR11 subgroups Ia and Ib have also been suggested to be the main potential DMSP consumers [64], although Roseobacter sp. also metabolise DMSP [65]. Growth experiments with a Roseobacter isolate also revealed its potential plasticity in metabolism, by demonstrating a shift from DMS oxidation and DMSP degradation under aerobic conditions to DMSO (and nitrate) reduction under anaerobic conditions [66]. Alternatively, Thume et al. [67] have recently reported that a new sulfur metabolite dimethylsulfoxonium propionate (DMSOP) is synthesized by several DMSP-producing phytoplankton and marine bacteria, which is further metabolized (by marine bacteria) to DMSO. On average, $\mathrm{DMSO}_{\mathrm{d}}$ accounted for $55 \%$ of $\mathrm{DMSO}_{\mathrm{t}}$ and showed no obvious trends over the sampling period. The concentration of $\mathrm{DMSO}_{\mathrm{t}}$ in surface waters also showed a significant relationship with dinoflagellate abundance $(r=0.498, n=19, p<0.05)$.

The biological consumption rates of DMS determined during this temperate coastal study were generally in the same range as those reported for coastal Antarctic [20] and subarctic Pacific waters [65]. In these polar waters, Asher et al. [20,68] suggest that their measured gross DMS loss/consumption rates should largely reflect biological consumption owing to low calculated DMS photo-oxidation rates. Biological DMS consumption rates were reportedly lower in the Ross Sea, Antarctica $\left(0.02-8.8 \mathrm{nM} \mathrm{d}^{-1}\right)$, possibly because of lower temperatures minimizing bacterial activity [13]. Biological processes are generally reported to dominate DMS removal compared with sea-air flux, photo-oxidation, and mixing at the base of the mixed layer $[20,68,69]$. Our biological consumption rates of DMS also showed a statistically significant positive linear correlation with both the numbers of the dinoflagellate Scrippsiella 
trochoidea $(n=11, r=0.9858 p<0.001)$ and the diatoms Pseudo-nitzschia pungens $(n=11, r=0.9908$, $p<0.001)$ and Leptocylindrus danicus $(n=11, r=0.8543, p<0.001)$, where the numbers of phytoplankton cells varied between $<0.04$ and $7.68,<0.16$ and 2.6 , and $<0.10$ and 196.0 cells $\mathrm{mL}^{-1}$, respectively. The most noticeable was the peak in DMS BC during June, which coincided with an increase in the numbers of Scrippsiella trochoidea (from average background of 0.16 to 7.92 cells $\mathrm{mL}^{-1}$ ), which accounted for $\sim 72 \%$ of all the dinoflagellates. Despite generally occurring in relatively low numbers (cf. $\sim 25$ cells $\mathrm{mL}^{-1}$ at L4 reported in Archer et al. [55]), Scrippsiella trochoidea is a prolific DMSP producer, with cellular concentrations reported as high as millimolar [70] or 174-380 pg DMSP cell $^{-1}[58,71]$. The bacterial species associated with Scrippsiella trochoidea in culture have been shown to consume DMS, mostly oxidising it to DMSO [72]. We cannot confirm DMS oxidation to DMSO during these June experiments as we did not undertake complimentary stable tracer DMSO analysis on these dates. The biological turnover time for DMS at station L4 ranged between 0.2 and 1.8 days, in agreement with previous marine estimates $[30,68]$, and showed the quickest turnover coincident with maximum rates of DMS BC. DMS produced from DMSP cleavage was highly variable at our coastal station, ranging from non-detectable to $21.5 \mathrm{nM} \mathrm{d}^{-1}$ (average $9.1 \pm 9.3 \mathrm{nM} \mathrm{d}^{-1}, n=6$ ). Generally, these rates are in the range previously reported for a variety of marine environments $[15,20,30,68]$. Our rates of DMSP $\mathrm{d}_{\mathrm{d}}$ cleavage correlated with the abundance of the grazing ciliate Tontonia ovalis $(n=6, r=0.9790, p<0.001)$ and large flagellates $(\geq 15 \mu \mathrm{m}$, where $n=6, r=0.8346, p<0.05)$, possibly suggesting enhanced DMSP lyase activity owing to grazing pressures, perhaps as some chemical "don't eat me" cue [73], or because of physical disruption of cells during grazing [74]. DMS produced from DMSO reduction was not detectable at the coastal station L4, in sharp contrast to Antarctic environments [15,20]. Following a simple DMS mass balance approach, which assumes that the observed net change in the DMS pool must equal the DMS produced by DMSP cleavage and DMSO reduction minus biological DMS consumption [15], allows an assessment of the significance of other DMS sources. Our data suggest that up to $42.9 \mathrm{nM} \mathrm{d}^{-1}$ of DMS could be excreted from biological particles (and/or the conversion of unlabeled DMSP or DMSO that has leaked from cells into the dissolved pool [15]). However, a correlation between estimated DMS release from particles and biological consumption $(n=11, r=0.7903, p<0.001)$ suggests a tight coupling in coastal waters.

The biological loss of $\mathrm{DMSO}_{\mathrm{d}}$ due to assimilation and dissimilation (determined using radiotracers) ranged between 2.9 and $111 \mathrm{nM} \mathrm{d}^{-1}$. However, the maximum loss rate was driven by the relatively high $\mathrm{DMSO}_{\mathrm{d}}$ concentration of $62 \mathrm{nM}$ compared with the otherwise seasonal average of $9.2 \pm 6.4 \mathrm{nM}$. Excluding the observed maxima, radiotracer-derived $\mathrm{DMSO}_{\mathrm{d}}$ biological consumption ranged between 2.9 and $24.3 \mathrm{nM} \mathrm{d}^{-1}$. Independent stable tracer experiments using ${ }^{13} \mathrm{C}_{2}$-DMSO during July-August also suggest gross biological DMSO consumption rates of $23.3 \pm 5.9$ and $25.6 \pm 11.6 \mathrm{nM} \mathrm{d}^{-1}$ (Figure $4 \mathrm{c}$ ). A comparison between stable tracer-derived microbial $\mathrm{DMSO}_{\mathrm{d}}$ biological consumption rates and radiotracer-derived $\mathrm{DMSO}_{\mathrm{d}}$ assimilation plus dissimilation loss rates during July suggests that the majority of microbial $\mathrm{DMSO}_{\mathrm{d}}$ loss $\left(23.2 \pm 5.9 \mathrm{nM} \mathrm{d}^{-1}\right.$ Figure $\left.5 \mathrm{a}\right)$ was because of microbial dissimilation of $\mathrm{DMSO}_{\mathrm{d}}$ to $\mathrm{CO}_{2}\left(24.2 \pm 0.3 \mathrm{nM} \mathrm{d}{ }^{-1}\right.$, Figure $\left.5 \mathrm{a}\right)$, presumably in order to provide reducing power. However, during August, stable tracer-derived gross consumption rates of $25.6 \pm 11.6 \mathrm{nM} \mathrm{d}^{-1}$ were higher than the radiochemical-derived $\mathrm{DMSO}_{\mathrm{d}}$ assimilation plus dissimilation combined rate of $10.5 \pm 0.3 \mathrm{nM} \mathrm{d}^{-1}$ (Figure $5 \mathrm{~b}$ ), suggesting that other $\mathrm{DMSO}_{\mathrm{d}}$ loss reactions were dominant, for example, perhaps further oxidation to dimethylsulphone [32], as we did not detect any reduction to DMS. Our experimental design precluded DMSO losses owing to photochemical reactions [75].

Excluding the maxima, the biological DMSO loss rates (assimilation plus dissimilation) in coastal waters determined in our study averaged $11.9 \pm 2.8 \mathrm{nM} \mathrm{d}^{-1}$, which is comparable to DMSO $\mathrm{D}_{\mathrm{d}}$ loss rates of 4-10 $\mathrm{nM} \mathrm{d}^{-1}$ determined via changes in concentrations of DMSO during dark incubations [30,76]. By comparison, biological $\mathrm{DMSO}_{\mathrm{d}}$ uptake rates determined at coastal stations in the Gulf of Mexico were lower than ours, ranging between 1.7 and $3.9 \mathrm{nM} \mathrm{d}^{-1}$ [31], possibly because of comparatively lower chlorophyll a levels and the influence of riverine outflows during the latter study. Turnover times of $\mathrm{DMSO}_{\mathrm{d}}$ were estimated from the reciprocal of the total apparent rate constant $\left({ }^{14} \mathrm{C}\right.$-derived assimilation 
plus dissimilation) at $0.6-1.9 \mathrm{~d}$, which is comparable to $0.5-0.7 \mathrm{~d}$ derived from the ${ }^{13} \mathrm{C}_{2}$-DMSO stable tracer experiments, and not dissimilar to previous literature estimates of $2-5 \mathrm{~d}[30,76]$. However, Tyssebotyn et al. [31] report a much slower median $\mathrm{DMSO}_{\mathrm{d}}$ turnover time of $7.4 \mathrm{~d}$ in coastal river plume stations, presumably because of their lower $\mathrm{DMSO}_{\mathrm{d}}$ oxidation rates. The majority of $\mathrm{DMSO}_{\mathrm{d}}$ utilized by the heterotrophic community was respired $(>94 \%)$, like a variety of other low nano-molar organic methylated substrates in seawater such as methanol, methylamines, glycine betaine, and trimethylamine N-oxide [77-81], although up to $30 \%$ of acetaldehyde was assimilated into biomass by SAR11 bacterioplankton in culture [82]. The microbial oxidation of $\mathrm{C} 1$ units, in these cases, methyl groups, has been previously hypothesized to be a significant conduit by which dissolved organic carbon is recycled to $\mathrm{CO}_{2}$ in the upper ocean [81], and our $\mathrm{DMSO}_{\mathrm{d}}$ respiration data lend support to this idea. Tyssebotyn et al. [31] similarly concluded that DMSO was mostly metabolized for energy, although they reported a lower proportion of dissimilation (62-75\%) compared with our data, and suggested that the proportion metabolized does not change with dissolved carbon or nutrient status. Our seasonally resolved data suggest that DMSO assimilation is highest during summer (up to 5\%) when nutrients are depleted, and lowest during nutrient replete winter months, in agreement with an annual study of methanol metabolism at station L4 [80].

The rates of biological consumption of DMSP $\mathrm{d}\left(75.7\right.$ and $48.4 \mathrm{nM} \mathrm{d}^{-1}$ for 21 July and 26 August respectively, Figure 5) were between 9-19 and 2-3 times higher than that of DMS and $\mathrm{DMSO}_{d}$, respectively, under both medium $(14.0 \mathrm{nM})$ and low DMS $(1.0 \mathrm{nM})$ conditions (Figure 5). During these two sampling dates, we did not detect any bacterial enzymatic conversion of DMSP ${ }_{d}$ to DMS, which perhaps indicates sustained bacterial sulfur demand and consumption of $\mathrm{DMSP}_{\mathrm{d}}$ via demethylation or demethiolation pathways [1,83]. Although it has been demonstrated that Synechococcus cells (Figure 2c) assimilate DMSP sulfur [84], our dark incubations would minimise their contribution to DMSP uptake. Our biological consumption rates of $\mathrm{DMSP}_{\mathrm{d}}$ are within the range of marine $\mathrm{DMSP}_{\mathrm{d}}$ turnover rates summarized in Kiene et al. [83], where up to $100 \%$ of DMSP $_{d}$ was reportedly metabolized via demethylation. The turnover times of $\mathrm{DMSP}_{\mathrm{d}}$ were estimated at $0.3 \pm 0.1 \mathrm{~d}$, in agreement with other marine waters [30]. DMS has been previously demonstrated to be metabolized by bacteria much more slowly than DMSP ${ }_{d}$ [10], with our bacterial DMS consumption data suggesting that it is utilised up to 19 times slower than $\mathrm{DMSP}_{\mathrm{d}}$. Stable tracer derived biological consumption rates of $\mathrm{DMSO}_{\mathrm{d}}$ are intermediate between DMS and DMSP ${ }_{\mathrm{d}}$. The combined biological consumption of dissolved DMSP, DMS, and DMSO was $~ 77-108 \mathrm{nM} \mathrm{d}^{-1}$ (Figure 5). We estimate the contribution made by these dissolved organic species to both bacterial carbon and sulfur demand by assuming that bacterial heterotrophic production (BP) was $0.18 \pm 0.04(n=3)$ and $0.08 \pm 0.04(n=3) \mu \mathrm{g} \mathrm{C} \mathrm{L}^{-1} \cdot \mathrm{h}^{-1}$ during July and August, respectively (data derived from Sergeant et al. [80] using a theoretical leucine-to-carbon conversion factor of $1.55 \mathrm{~kg} \mathrm{C} \mathrm{mol} \mathrm{leu}^{-1}$ [85]). Bacterial respiration (BR) was calculated from production, where $\mathrm{BR}=3.69 \mathrm{BP}^{0.58}[86]$. Bacterial growth efficiency (BGE) was calculated in two different ways; firstly using production $(\mathrm{BP})$ and respiration $(\mathrm{BR})$ estimates $(\mathrm{BGE}=\mathrm{BP} /(\mathrm{BP}+\mathrm{BR}))$, and secondly using chlorophyll a concentrations (Figure 1C). Bacterial carbon demand was calculated by dividing bacterial production (BP) by the average of the two estimates of BGE as $3.35 \pm 0.83$ and $1.74 \pm 0.79 \mu$ moles $\mathrm{C} \mathrm{L}^{-1}$ $\mathrm{d}^{-1}$ for July and August, respectively. The rates of biological consumption of dissolved DMSP, DMS, and DMSO were converted to carbon units (by multiplying by 5,2 , and 2, respectively) to yield rates of 0.44 and $0.30 \mu \mathrm{mol} \mathrm{C} \mathrm{L} \mathrm{L}^{-1} \mathrm{~d}^{-1}$ for July and August, respectively. This suggests that these three organic sulfur species could support $13 \%-17 \%$ of the estimated bacterial carbon demand during summer months. Bacterial carbon demand was converted to sulfur demand, assuming a carbon to sulfur ratio of $86[11,87]$, resulting in 0.04 and $0.02 \mu$ moles S L ${ }^{-1} \cdot \mathrm{d}^{-1}$ for July and August, respectively. Calculations suggest that DMSP ${ }_{d}$ alone could supply all of the sulfur to meet microbial demand (195\% and $234 \%$ for July and August, respectively, DMSP S microbial consumption/bacterial S demand). Even if only 50\% of DMSP $\mathrm{d}_{\mathrm{d}}$ sulfur used by bacteria was incorporated into biomass, that is, used for assimilatory rather than dissimilatory purposes, then the combined uptake of DMS, DMSP $\mathrm{d}_{\mathrm{d}}$, and $\mathrm{DMSO}_{\mathrm{d}}(277 \%$ and $378 \%$ for July and August, respectively) would still meet bacterial sulfur demands. DMSP $\mathrm{d}_{\mathrm{d}}$ is known to be 
a widespread substrate for heterotrophic bacteria, with literature suggesting that it can provide up to $15 \%$ and $100 \%$ of their carbon and sulfur requirements, respectively $[11,83]$. Similar calculations for $\mathrm{DMSO}_{\mathrm{d}}$ suggest that this compound alone could supply 60-126\% and 1.4-2.9\% of bacterial sulfur and carbon demand, respectively. Bacterial utilization of such reduced organic sulfur species over dissolved sulfate is thought to be energetically preferable for the synthesis of methionine [88].

In summary, these data demonstrate that, throughout the productive months of the year at a temperate coastal location, the biological consumption of DMS is highly variable, and largely decoupled from the amount of DMS produced from cleavage of $\mathrm{DMSP}_{\mathrm{d}}$, and its oxidation to $\mathrm{DMSO}_{\mathrm{d}}$. Stable tracer experiments suggest that DMS produced from the reduction of $\mathrm{DMSO}_{\mathrm{d}}$ is not a common pathway in temperate coastal waters, which contrasts to Antarctic regions. Microbial consumption rates of organic sulfur species follow the order $\mathrm{DMSP}_{\mathrm{d}}>\mathrm{DMSO}_{\mathrm{d}}>\mathrm{DMS}$, where the microbial dissimilation of $\mathrm{DMSO}_{\mathrm{d}}$ to $\mathrm{CO}_{2}$ can be a significant loss pathway for $\mathrm{DMSO}_{\mathrm{d}}$ in coastal waters. However, what controls the loss of $\mathrm{DMSO}_{\mathrm{d}}$ and the identification of bacteria responsible (and their biochemical pathways/genes) in seawater largely remains elusive.

Supplementary Materials: The following are available online at http://www.mdpi.com/2076-2607/8/3/337/s1, Figure S1: Typical time course experiments at the coastal station L4 showing the amount of radioactive carbon from the added ${ }^{14} \mathrm{C}_{2}$-DMSO that was used during (a) assimilation into particulate material and (b) oxidation to ${ }^{14} \mathrm{CO}_{2}$ after radiotracer addition of $\leq 1.6 \mathrm{nM}$. Where DPM is disintegrations per minute $\left(1 \mathrm{DPM}=4.51 \times 10^{-13} \mathrm{Ci}\right)$. Error bars represent \pm 1 standard deviation of three replicate samples.

Author Contributions: Conceptualization, J.L.D., F.E.H., and H.S.; methodology, J.L.D., F.E.H., and J.A.S.; formal analysis, J.L.D., F.E.H., and J.A.S.; writing-original draft preparation, J.L.D.; writing-review and editing, J.L.D. and F.E.H.; funding acquisition, J.L.D., F.E.H., and H.S. All authors have read and agreed to the published version of the manuscript.

Funding: This work was funded by a NERC grant NE/L004151/1 and the Western Channel Observatory, which is is funded by the UK Natural Environment Research Council through its National Capability Long-term Single Centre Science Programme, Climate Linked Atlantic Sector Science, grant number NE/R015953/1.

Acknowledgments: We thank Denise Cummings and the boat crew of the RV Quest for sampling at station L4, which is provided by the Plymouth Marine Laboratory, Western Channel Observatory (www. westernchannelobservatory.org.uk). We also thank Glen Tarran, Claire Widdicombe, and Malcolm Woodward for provision of flow cytometry, microscope phytoplankton identification and enumeration, and nutrients, respectively.

Conflicts of Interest: The authors declare no conflict of interest.

\section{References}

1. Levasseur, M. Impact of Arctic meltdown on the microbial cycling of sulfur. Nat. Geosci. 2013, 6, 691-700. [CrossRef]

2. Lovelock, J.E.; Maggs, R.J.; Rasmussen, R.A. Atmospheric dimethyl sulphide and the natural sulphur cycle. Nature 1972, 237, 452-453. [CrossRef]

3. Kettle, A.J.; Andreae, M.O. Flux of dimethylsulfide from the oceans: A comparison of updated datasets and flux models. J. Geophys. Res. Atmos. 2000, 105, 26793-26808. [CrossRef]

4. Curson, A.R.; Todd, J.D.; Sullivan, M.; Johnston, A.W. Catabolism of dimethylsulphoniopropionate: Microorganisms, enzymes and genes. Nat. Rev. Microbiol. 2011, 9, 849-859. [CrossRef] [PubMed]

5. Galí, M.; Simó, R. A meta-analysis of oceanic DMS and DMSP cycling processes: Disentangling the summer paradox. Glob. Biogeochem. Cycles 2015, 29, 496-515. [CrossRef]

6. Kiene, R.P.; Bates, T.S. Biological removal of dimethyl sulphide from sea water. Nature 1990, 345, 702-705. [CrossRef]

7. Herrmann, M.; Najjar, R.G.; Neeley, A.R.; Vila-Costa, M.; Dacey, J.W.; DiTullio, G.R.; Kieber, D.J.; Kiene, R.P.; Matrai, P.A.; Simo, R.; et al. Diagnostic modeling of dimethylsulfide production in coastal water west of the Antarctic Peninsula. Cont. Shelf Res. 2012, 32, 96-109. [CrossRef]

8. Andreae, M.O. Ocean-atmosphere interactions in the global biogeochemical sulfur cycle. Mar. Chem. 1990, 30, 1-29. [CrossRef]

9. Von Glasow, R.V.; Crutzen, P.J. Model study of multiphase DMS oxidation with a focus on halogens. Atmos. Chem. Phys. 2004, 4, 589-608. [CrossRef] 
10. Kiene, R.P.; Linn, L.J. The fate of dissolved dimethylsulfoniopropionate (DMSP) in seawater: Tracer studies using ${ }^{35}$ S-DMSP. Geochim. Cosmochim. Acta 2000, 64, 2797-2810. [CrossRef]

11. Simó, R.; Archer, S.D.; Pedrós-Alió, C.; Gilpin, L.; Stelfox-Widdicombe, C.E. Coupled dynamics of dimethylsulfoniopropionate and dimethylsulfide cycling and the microbial food web in surface waters of the North Atlantic. Limnol. Oceanogr. 2002, 47, 3-61. [CrossRef]

12. Vila-Costa, M.; Kiene, R.P.; Simó, R. Seasonal variability of the dynamics of dimethylated sulfur compounds in a coastal northwest Mediterranean site. Limnol. Oceanogr. 2008, 53, 198-211. [CrossRef]

13. del Valle, D.A.; Kieber, D.J.; Toole, D.A.; Brinkley, J.; Kienea, R.P. Biological consumption of dimethylsulfide (DMS) and its importance in DMS dynamics in the Ross Sea, Antarctica. Limnol. Oceanogr. 2009, 54, 785-798. [CrossRef]

14. Del Valle, D.A.; Kieber, D.J.; Kiene, R.P. Depth-dependent fate of biologically consumed dimethylsulfide in the Sargasso Sea. Mar. Chem. 2007, 103, 197-208. [CrossRef]

15. Asher, E.C.; Dacey, J.W.H.; Mills, M.M.; Arrigo, K.R.; Tortell, P.D. High concentrations and turnover rates of DMS, DMSP and DMSO in Antarctic sea ice. Geophys. Res. Letts. 2011, 38, L23609. [CrossRef]

16. Steinke, M.; Daniel, C.; Kirst, G.O. DMSP Lyase in Marine Macro- and Microalgae. In Biological and Environmental Chemistry of DMSP and Related Sulfonium Compounds; Kiene, R.P., Visscher, P.T., Keller, M.D., Kirst, G.O., Eds.; Springer: Boston, MA, USA, 1996; pp. 317-324.

17. Stefels, J.; van Boekel, W.H.M. Production of DMS from dissolved DMSP in axenic cultures of the marine phytoplankton species Phaeocystis sp.. Mar. Ecol. Prog. Ser. 1993, 97, 11-18. [CrossRef]

18. Spiese, C.E. Cellular Production and Losses of Dimethylsulfide in Marine Phytoplankton. Ph.D. Thesis, State University of New York College of Environmental Science and Forestry, Syracuse, NY, USA, 2010.

19. González, J.M.; Kiene, R.P.; Moran, M.A. Transformation of sulphur compounds by an abundant lineage of the marine bacteria in the $\alpha$-subclass of the class Proteobacteria. Appl. Environ. Microbiol. 1999, 65, 3810-3819. [CrossRef]

20. Asher, E.C.; Dacey, J.W.H.; Stukel, M.; Long, M.C.; Tortell, P.D. Processes driving seasonal variability in DMS, DMSP, and DMSO concentrations and turnover in coastal Antarctic waters. Limnol. Oceanogr. 2017, 62, 104-124. [CrossRef]

21. Stefels, J. Physiological aspects of the production and conversion of DMSP in marine algae and higher plants. J. Sea Res. 2000, 43, 183-197. [CrossRef]

22. Simó, R. Production of atmospheric sulfur by oceanic plankton: Biogeochemical, ecological and evolutionary links. Trends Ecol. Evol. 2001, 16, 287-294. [CrossRef]

23. Simó, R.; Grimalt, J.O.; Albaigés, J. Dissolved dimethylsulphide, dimethylsulphoniopropionate and dimethylsulphoxide in western Mediterranean waters. Deep Sea Res. II 1997, 44, 929-950. [CrossRef]

24. Zindler, C.; Bracher, A.; Marandino, C.A.; Taylor, B.; Torrecilla, E.; Kock, A.; Bange, H.W. Sulphur compounds, methane, and phytoplankton: Interactions along a north-south transit in the western Pacific Ocean. Biogeosciences 2013, 10, 3297-3311. [CrossRef]

25. Lee, P.A.; de Mora, S.J. Intracellular dimethylsulphoxide (DMSO) in unicellular marine algae: Speculations on its origin and possible biological role. J. Phycol. 1999, 35, 8-18.

26. Chen, Y.; Patel, N.A.; Crombie, A.; Scrivens, J.H.; Murrell, J.C. Bacterial flavin-containing monooxygenase is trimethylamine monooxygenase. Proc. Natl. Acad. Sci. USA 2011, 108, 17791-17796. [CrossRef]

27. Lidbury, I.; Kröber, E.; Zhang, Z.; Zhu, Y.; Murrell, J.C.; Chen, Y.; Schäfer, H. A mechanism for bacterial transformation of dimethylsulfide to dimethylsulfoxide: A missing link in the marine organic sulfur cycle. Environ. Microb. 2016, 18, 2754-2766. [CrossRef]

28. Andreae, M.O. Dimethylsulfoxide in marine and freshwaters. Limnol. Oceanogr. 1980, 25, $1054-1063$. [CrossRef]

29. Sunda, W.; Kieber, D.J.; Kiene, R.P.; Huntsman, S. An antioxidant function for DMSP and DMS in marine algae. Nature 2002, 418, 317-320. [CrossRef]

30. Simó, R.; Pedrós-Alió, C.; Malin, G.; Grimalt, J.O. Biological turnover of DMS, DMSP and DMSO in contrasting open-sea waters. Mar. Ecol. Prog. Ser. 2000, 203, 1-11. [CrossRef]

31. Tyssebotn, I.M.B.; Kinsey, J.D.; Kieber, D.J.; Kiene, R.P.; Rellinger, A.N.; Motard-Côté, J. Concentrations, biological uptake, and respiration of dissolved acrylate and dimethylsulfoxide in the northern Gulf of Mexico. Limnol. Oceanogr. 2017, 62, 1198-1218. [CrossRef] 
32. Hatton, A.D.; Darroch, L.; Malin, G. The role of dimethylsulphoxide in the marine biogeochemical cycle of dimethylsuphide. Oceanogr. Mar. Biol. Annu. Rev. 2004, 42, 29-56.

33. Spiese, C.E.; Kieber, D.J.; Nomura, C.T.; Kiene, R.P. Reduction of dimethylsulfoxide to dimethylsulfide by marine phytoplankton. Limnol. Oceanogr. 2009, 54, 560-570. [CrossRef]

34. McCrindle, S.L.; Kappler, U.; McEwan, A.G. Microbial dimethylsulfoxide and trimethylamine-N-oxide respiration. Adv. Microb. Physiol. 2005, 50, 147-198. [PubMed]

35. Vogt, C.; Rabenstein, A.; Rethmeier, J.; Fischer, U. Dimethyl sulphoxide reduction with reduced sulphur compounds as electron donors by anoxygenic phototrophic bacteria. Microbiology 1997, 143, 767-773. [CrossRef]

36. deBont, J.A.M.; van Dijken, J.P.; Harder, W. Dimethyl sulphoxide and dimethyl sulfide as a carbon, sulphur and energy source for growth of Hyphomicrobium. S. J. Gen. Microbiol. 1981, 127, 315-323.

37. Borodina, E.; Kelly, D.P.; Rainey, F.A.; Ward-Rainey, N.L.; Wood, A.P. Dimethylsulfone as a growth substrate for novel methylotrophic species of Hyphomicrobium and Arthrobacter. Arch. Microbiol. 2000, 173, 425-437. [CrossRef]

38. Kim, H.G.; Doronina, N.V.; Trostsenko, Y.A.; Kim, S.W. Methylophaga aminisulfidivorans sp. nov., a restricted facultatively methylotrophic marine bacterium. Int. J. Evol. Syst. Microbiol. 2007, 57, 2096-2101. [CrossRef]

39. Smyth, T.J.; Fishwick, J.R.; Al-Moosawi, L.; Cummings, D.G.; Harris, C.; Kitidis, V.; Rees, A.; Martinez-Vicente, V.; Woodward, E.M.S.W. A broad spatio-temporal view of the Western English Channel observatory. J. Plankton Res. 2010, 32, 585-601. [CrossRef]

40. Tilstone, G.; Smyth, T.A.P.; Hutson, R. Measured and remotely sensed estimates of primary production in the Atlantic Ocean from 1998 to 2005. Deep Sea Res. II 2009, 56, 918-930. [CrossRef]

41. Brewer, P.G.; Riley, J.P. The automatic determination of nitrate in sea water. Deep Sea Res. 1965, 12, 765-772. [CrossRef]

42. Grasshoff, H. Methods of Seawater Analysis; Chemie: Weinheim, Germany; New York, NY, USA, 1976 ; p. 317.

43. Zhang, J.Z.; Chi, J. Automated analysis of nanomolar concentrations of phosphate in natural waters with liquid waveguides. Environ. Sci. Technol. 2002, 36, 1048-1053. [CrossRef]

44. Tarran, G.A.; Bruun, J.T. Nanoplankton and picoplankton in the Western English Channel: Abundance and seasonality from 2007-2013. Prog. Oceanogr. 2015, 137, 446-455. [CrossRef]

45. Widdicombe, C.E.; Eloire, D.; Harbour, D.; Harris, R.P.; Somerfield, P.J. Long-term phytoplankton community dynamics in the Western English Channel. J. Plankton Res. 2010, 32, 643-655. [CrossRef]

46. Simó, R.; Grimalt, J.O.; Albaigés, J. Sequential method for the determination of nanomolar concentrations of dimethyl sulfoxide in natural waters. Anal. Chem. 1996, 68, 1493-1498. [CrossRef]

47. Simó, R.; Vila-Costa, M. Ubiquity of algal dimethylsulfoxide in the surface ocean: Geographic and temporal distribution patterns. Mar. Chem. 2006, 100, 136-146. [CrossRef]

48. Archer, S.D.; Kimmance, S.A.; Stephens, J.A.; Hopkins, F.E.; Bellerby, R.G.J.; Schulz, K.G.; Piontek, J.; Engel, A. Contrasting responses of DMS and DMSP to ocean acidification in Arctic waters. Biogeosciences 2013, 10, 1893-1908. [CrossRef]

49. Townsend, D.W.; Keller, M.D. Dimethylsulfide (DMS) and dimethylsulfoniopropionate (DMSP) in relation to phytoplankton in the Gulf of Maine. Mar. Ecol. Prog. Ser. 1996, 137, 229-241. [CrossRef]

50. Simó, R.; Malin, G.; Liss, P. Refinement of the borohydride reduction method for trace analysis of dissolved and particulate dimethyl sulfoxide in marine water samples. Anal. Chem. 1998, 70, 4864-4867. [CrossRef]

51. Kinsey, J.D.; Kieber, D.J. Microwave preservation method for DMSP, DMSO and acrylate in unfiltered seawater and phytoplankton culture samples. Limnol. Oceanogr. Methods 2016, 14, 196-209. [CrossRef]

52. Kiene, R.P.; Hoffmann Williams, L.P. Glycine betaine uptake, retention, and degradation by microorganisms in seawater. Limnol. Oceanogr. 1998, 43, 1592-1603. [CrossRef]

53. Kiene, R.P.; Slezak, D. Low dissolved DMSP concentrations in seawater revealed by small-volume gravity filtration and dialysis sampling. Limnol. Oceanogr: Methods 2006, 4, 80-95. [CrossRef]

54. Goodwin, K.D.; Schaefer, J.K.; Oremland, R.S. Bacterial oxidation of dibromomethane and methyl bromide in natural waters and enrichement cultures. Appl. Environ. Microbiol. 1998, 64, 4629-4636. [CrossRef] [PubMed]

55. Archer, S.D.; Cummings, D.G.; Llewellyn, C.A.; Fishwick, J.R. Phytoplankton taxa, irradiance and nutrient availability determine the seasonal cycle of DMSP in temperate shelf seas. Mar. Ecol. Prog. Ser. 2009, 394, 111-124. [CrossRef] 
56. Zindler, C.; Peeken, I.; Marandino, C.A.; Bange, H.W. Environmental control on the variability of DMS and DMSP in the Mauritanian upwelling region. Biogosciences 2012, 9, 1041-1051. [CrossRef]

57. Niki, T.; Kunugi, M.; Otsuki, A. DMSP-lyase activity in five marine phytoplankton species: Its potential importance in DMS production. Mar. Biol. 2000, 136, 759-764. [CrossRef]

58. Caruana, A.M.N.; Steinke, M.; Turner, S.M.; Malin, G. Concentrations of dimethylsulphoniopropionate and activities of dimethylsulphide-producing enzymes in batch cultures of nine dinoflagellate species. Biogeochemistry 2012, 110, 87-107. [CrossRef]

59. Steinke, M.; Malin, G.; Archer, S.D.; Burkill, P.H.; Liss, P.S. DMS production in a coccolithophorid bloom: Evidence for the importance of dinoflagellate DMSP lyases. Aquat. Microb. Ecol. 2002, 26, 259-270. [CrossRef]

60. Franklin, D.J.; Poulton, A.J.; Steinke, M.; Young, J.; Peeken, I.; Malin, G. Dimethylsulphide, DMSP-lyase activity and microplankton community structure inside and outside of the Mauritanian upwelling. Prog. Oceanogr. 2009, 83, 134-142. [CrossRef]

61. Michaud, S.; Levasseur, M.; Cantin, G. Seasonal variations in dimethylsulfoniopropionate and dimethylsulfide concentrations in relation to the plankton community in the St. Lawrence Estuary. Estuar. Coast. Shelf Sci. 2007, 71, 741-750. [CrossRef]

62. Speeckaert, G.; Borges, A.V.; Champenois, W.; Royer, C.; Gypens, N. Annual cycle of dimethylsulfoniopropionate (DMSP) and dimethylsulfoxide (DMSO) related to phytoplankton succession in the Southern North Sea. Sci. Total Environ. 2018, 622, 362-372. [CrossRef]

63. Boden, R.; Murrell, J.C.; Schäfer, H. Dimethylsulfide is an energy source for the heterotrophic marine bacterium Sagittula stellata. FEMS Microbiol. Lett. 2011, 322, 188-193. [CrossRef]

64. Cui, Y.; Suzuki, S.; Omori, Y.; Wong, A.-K.; Ijichi, M.; Kaneko, R.; Kameyama, S.; Tanimoto, H.; Hamasaki, K. Abundance and distribution of dimethylsulfoniopropionate degradation genes and the corresponding bacterial community structure are dimethyl sulfide hot spots in the tropical and subtropical Pacific Ocean. Appl. Environ. Microbiol. 2015, 81, 4184-4194. [CrossRef] [PubMed]

65. Newton, R.J.; Griffin, L.E.; Bowles, K.M.; Meile, C.; Gifford, S.; Givens, C.E.; Howard, E.C.; King, E.; Oakley, C.A.; Reisch, C.Y.; et al. Genome characteristics of a generalist marine bacterial lineage. ISME J. 2010, 4, 784-798. [CrossRef] [PubMed]

66. Kanukollu, S.; Wemheuer, B.; Herber, J.; Billerbeck, S.; Lucas, J.; Daniel, R.; Simon, M.; Cypionka, H.; Engelen, B. Distinct compositions of free-living, particle-associated and benthic communities of the Roseobacter group in the North Sea. FEMS Microbiol. Ecol. 2016, 92, fiv145. [CrossRef] [PubMed]

67. Thume, K.; Gebser, B.; Chen, L.; Meyer, N.; Kieber, D.J.; Pohnert, G. The metabolite dimethylsulfoxonium propionate extends the marine organosulfur cycle. Nature 2018, 563, 412-415. [CrossRef] [PubMed]

68. Asher, E.; Dacey, J.W.; Ianson, D.; Peña, A.; Tortell, P.D. Concentrations and cycling of DMS, DMSP, and DMSO in coastal and offshore waters of the Subarctic Pacific during summer, 2010-2011. J. Geophys. Res. Oceans 2017, 122, 3269-3286. [CrossRef]

69. Yang, M.; Archer, S.D.; Blomquist, B.W.; Ho, D.T.; Lance, V.P.; Torres, R.J. Lagrangian evolution of DMS during the Southern Ocean gas exchange experiment: The effects of vertical mixing and biological community shift. J. Geophys. Res. Oceans 2013, 118, 6774-6790. [CrossRef]

70. Hatton, A.D.; Wilson, S.T. Particulate dimethylsulphoxide and dimethylsulphoniopropionate in phytoplankton cultures and Scottish coastal waters. Aquat. Sci. 2007, 69, 330-340. [CrossRef]

71. Keller, M.D.; Bellows, W.K.; Guillard, R.R.L. Dimethylsulfide production in marine phytoplankton. ACS Symp. Ser. 1989, 393, 167-182.

72. Hatton, A.D.; Shenoy, D.M.; Hart, M.C.; Mogg, A.; Green, D.H. Metabolism of DMSP, DMS and DMSO by the cultivable bacterial community associated with the DMSP-producing dinoflagellate Scrippsiella trochoidea. Biogeochemistry 2012, 110, 131-146. [CrossRef]

73. Strom, S.; Wolfe, G.; Holmes, J.; Stecher, H.; Shimeneck, C.; Lambert, S. Chemical defense in the microplankton I: Feeding and growth rates of heterotrophic protists on the DMS-producing phytoplankter Emiliania huxleyi. Limnol. Oceanogr. 2003, 48, 217-229. [CrossRef]

74. Evans, C.; Kadner, S.V.; Darroch, L.J.; Wilson, W.H.; Liss, P.S.; Malin, G. The relative significance of viral lysis and microzooplankton grazing as pathways of dimethylsulfoniopropionate (DMSP) cleavage: An Emiliania huxleyi culture study. Limnol. Oceanogr. 2007, 52, 1036-1045. [CrossRef]

75. Lee, P.A.; de Mora, S.J.; Levasseur, M. A review of dimethylsulfoxide in aquatic environments. Atmos. Ocean 1999, 37, 439-456. [CrossRef] 
76. Kiene, R.P.; Gerard, G. Determination of trace levels of dimethylsulphoxide (DMSO) in seawater and rainwater. Mar. Chem. 1994, 47, 1-12. [CrossRef]

77. Dixon, J.L.; Beale, R.; Nightingale, P.D. Microbial methanol uptake in northeast Atlantic waters. ISME J. 2011, 5, 704-716. [CrossRef]

78. Dixon, J.L.; Beale, R.; Nightingale, P.D. Rapid biological oxidation of methanol in the tropical Atlantic: Significance as a microbial carbon source. Biogeosciences 2011, 8, 2707-2716. [CrossRef]

79. Dixon, J.L.; Sargeant, S.; Nightingale, P.D.; Murrell, J.C. Gradients in microbial methanol uptake: Productive coastal upwelling waters to oligotrophic gyres in the Atlantic Ocean. ISME J. 2013, 7, 568-680. [CrossRef]

80. Sargeant, S.L.; Murrell, J.C.; Nightingale, P.D.; Dixon, J.L. Seasonal variability in microbial methanol utilisation in coastal waters of the western English Channel. Mar. Ecol. Prog. Ser. 2016, 550, 53-64. [CrossRef]

81. Sun, J.; Steindler, L.; Thrash, J.C.; Halsey, K.H.; Smith, D.P.; Carter, A.E.; Landry, Z.C.; Giovannoni, S.J. One carbon metabolism in SAR11 pelagic marine bacteria. PLoS ONE 2011, 6, e23973. [CrossRef]

82. Halsey, K.H.; Giovannoni, S.J.; Graus, M.; Zhao, Y.; Landry, Z.; Thrash, J.C.; Vergin, K.L.; de Gouw, J. Biological cycling of volatile organic carbon by phytoplankton and bacterioplankton. Limnol. Oceanogr. 2017, 62, 2650-2661. [CrossRef]

83. Kiene, R.P.; Linn, L.J.; Bruton, J.A. New and important roles for DMSP in marine microbial communities. J. Sea Res. 2000, 43, 209-224. [CrossRef]

84. Vila-Costa, M.; Simó, R.; Harada, H.; Gasol, J.M.; Slezak, D.; Kiene, R.P. Dimethylsulfoniopropionate uptake by marine phytoplankton. Science 2006, 314, 652-654. [CrossRef]

85. Simon, M.; Azam, F. Protein content and protein synthesis rates of planktonic marine bacteria. Mar. Ecol. Prog. Ser. 1989, 51, 201-213. [CrossRef]

86. Robinson, C. Heterotrophic bacterial respiration. In Microbial Ecology of the Oceans; Kirchman, D.L., Ed.; Wiley: Hoboken, NJ, USA, 2008; pp. 299-334.

87. Fagerbakke, K.M.; Heldal, M.; Norland, S. Content of carbon, nitrogen, oxygen, sulfur and phosphorus in native aquatic and cultured bacteria. Aquat. Microb. Ecol. 1996, 10, 15-27. [CrossRef]

88. Kiene, R.P.; Linn, L.J.; González, J.; Moran, M.A.; Bruton, J.A. Dimethylsulfoniopropionate and methanethiol are important precursors of methionine and protein-sulfur in marine bacterioplankton. Appl. Environ. Microbiol. 1999, 65, 4549-4558. [CrossRef] 